OPEN ACCESS

Edited by:

Mohamed M. Abdel-Daim,

Suez Canal University, Egypt

Reviewed by: Mohamed Kamel, Cairo University, Egypt Kazumichi Fujioka,

Kobe University, Japan

*Correspondence: Wentao Wang wwtdoctor02@163.com

Specialty section: This article was submitted to Inflammation Pharmacology,

a section of the journal

Frontiers in Pharmacology

Received: 07 July 2019 Accepted: 12 November 2019 Published: 28 November 2019

Citation:

Yang L, Zhang Z, Kong J and Wang W (2019) Systematic Review and Meta-Analysis of the Benefit and Safety of Preoperative Administration of Steroid in Patients Undergoing Liver Resection.

Front. Pharmacol. 10:1442 doi: 10.3389/fphar.2019.01442

\section{Systematic Review and Meta- Analysis of the Benefit and Safety of Preoperative Administration of Steroid in Patients Undergoing Liver Resection}

\author{
Lingpeng Yang ${ }^{1}$, Zifei Zhang ${ }^{1,2}$, Junjie Kong ${ }^{1}$ and Wentao Wang ${ }^{1 *}$ \\ ${ }^{1}$ Department of Liver Surgery, Liver Transplantation Center, West China Hospital of Sichuan University, Chengdu, China, \\ ${ }^{2}$ Department of General Surgery, The Affiliated Hospital of Xizang Minzu University, Xianyang, China
}

Objective: To evaluate the benefit and safety of preoperative administration of steroid in patients undergoing liver resection.

Methods: Randomized controlled trials (RCTs) which comparing preoperative administration of steroid in patients undergoing liver resection with control group were identified through a systematic literature search in PubMed, Embase, and Cochrane Library Central databases. This meta-analysis was carried out to assess the liver function, inflammatory response, and postoperative complications after liver surgery.

Results: Six RCTs including 411 patients were reviewed. The pooled result showed that there was no significant difference in the incidence of overall complications between the steroid group and the control group (OR, 0.57; 95\% $\mathrm{Cl}, 0.27-1.17 ; P=0.13)$. With respect to specific complications, no significant difference was detected between the two groups in infection complications (OR, 0.95; 95\% Cl, 0.13-6.95; $P=0.96)$, wound complications (OR, 0.65; 95\% Cl, 0.32-1.33; $P=0.24)$, liver failure $(\mathrm{OR}, 0.41 ; 95 \% \mathrm{Cl}$, $0.10-1.64 ; P=0.21$ ), bile leakage (OR, 0.57; 95\% Cl, 0.17-1.89; $P=0.36)$, and pleural effusion (OR, 1.24; 95\% Cl, 0.55-2.78; $P=0.60)$. For liver function, the level of serum total bilirubin (TB) on postoperative day 1 (POD 1) was significantly decreased associated with the intervention of steroid (MD, $-0.54 ; 95 \% \mathrm{Cl},-0.94$ to $-0.15 ; P=0.007$ ). However, no significant difference was found in the level of alanine aminotransferase (ALT) (MD, -69.39; 95\% Cl, -226.52 to 87.75; $P=0.39$ ) and aspartate aminotransferase (AST) (MD, $-93.44 ; 95 \% \mathrm{Cl},-275.68$ to $88.80 ; P=0.31$ ) on POD 1 between the two groups. Serum IL-6 level on POD 1 (MD, $-57.98 ; 95 \% \mathrm{Cl},-73.04$ to $-42.91 ; P<0.00001)$ and $\mathrm{CRP}$ level on POD 3 (MD, $-4.83 ; 95 \% \mathrm{Cl},-6.07$ to $-3.59 ; P<0.00001)$ were significantly reduced in the steroid group comparing to the control group. Compared with the control group, the level of early postoperative IL-10 was significant higher in the steroid group (MD, 17.89; $95 \% \mathrm{Cl}, 3.89$ to $31.89 ; P=0.01$ ). 
Conclusion: Preoperative administration of steroid in liver resection can promote the recovery of liver function and inhibit the inflammatory response without increasing postoperative complications. Further studies should focus on determining which patients would benefit most from the steroid.

Keywords: liver resection, steroid, inflammatory response, complications, meta-analysis, systematic review

\section{INTRODUCTION}

Major abdominal surgery such as liver resection results in an acute systemic inflammatory response characterized by hemodynamic and metabolic changes that produce and release various chemical mediators, including stress hormones, free radicals, and cytokines (Faist et al., 1996; Kohl and Deutschman, 2006). During liver resection, in order to reduce intraoperative blood loss, blockage to the inflow blood of the liver is needed (Pringle maneuver). The downside of this technique is the ischemia-reperfusion (IR) damage to liver cells (Teoh and Farrell, 2003). Inflammatory cytokines play a significant role in this process. Increased levels of inflammatory cytokines are connected with high postoperative mortality and morbidity (Baigrie et al., 1992). Consequently, more attention has evolved to regulating inflammatory responses that probably harmful to the surgery. Many protective measures have been applied to reduce hepatic IR injury, including intermittent or selective Pringle maneuver (Figueras et al., 2005; Kim et al., 2007) and multiple pharmacological interventions such as erythropoietin, vitamin E, branched chain amino acids, prostaglandin E (Bartels et al., 2004; Kawano et al., 2005; Ishikawa et al., 2010; Kato et al., 2010).

The properties of anti-inflammatory and immune modulating allow steroid to be widely used in a variety of diseases associated with inflammatory response (Barnes, 1998; Sapolsky et al., 2000). Some previous studies have showed that preoperative use of steroid may reduce pro-inflammatory cytokines, alleviate liver IR injury, maintain a stable coagulation function (Pulitano et al., 2007a; Saidi et al., 2007). However, steroid is a double-edged sword also with lots of drawbacks, which may lead to delayed wound healing, hyperglycemia, postoperative infection, impaired liver regeneration, and the reactivation of hepatitis virus (Holte and Kehlet, 2002; Polderman et al., 2019). The potential side effects of preoperative steroid use are of great concern in liver surgery. Considering the advantages and disadvantages, the use of steroid before liver resection is still controversial owing to absence of standard treatment guideline. Although some metaanalyses have discussed this topic (Li et al., 2013; Richardson et al., 2014), the authors ignored the high heterogeneity in the pooled results. Besides, the authors only analyzed the overall complications and they did not analyze the specific complications which were the significant parameters to evaluate the safety of

\footnotetext{
Abbreviations: IR, ischemia reperfusion; RCT, randomized controlled trial; TB, total bilirubin; CRP, C-reactive protein; IL-6, interleukin 6; IL-10, interleukin 10; ALT, alanine aminotransferase; AST, aspartate aminotransferase; OR, odds ratio; $\mathrm{MD}$, mean difference; $\mathrm{CI}$, confidence interval; POD, postoperative day.
}

preoperative steroid use. It is necessary to perform an updated and comprehensive meta-analysis by including the latest studies. Therefore, we performed this meta-analysis to evaluate the benefit and safety of preoperative administration of steroid in patients undergoing liver resection and provide a reference for clinical practice.

\section{MATERIALS AND METHODS}

\section{Literature Search Strategy}

This systematic review and meta-analysis was performed in accordance with the Preferred Reporting Items for Systematic Reviews and Meta-Analyses (PRISMA) Statement (Liberati et al., 2009). A systematic literature search was conducted independently by two authors (LY and ZZ) in the PubMed, Embase, and Cochrane Library Central databases through 4 May 2019. The search strategies were based on combinations of the following keywords: "hepatectomy" OR "liver resection" OR "hepatic resection" OR "liver surgery" OR "surgery of the liver" AND "steroids" OR "cortisone" OR "corticosteroids" OR "glucocorticoid" OR "glucocorticosteroids" OR "methylprednis" OR "methylprednisolone" OR "predniso" OR "prednisone" OR "dexamethasone" OR "hydrocortisone" In addition, a manual search of all references of retrieved articles was performed. The literature search was restricted to human studies and articles published in English.

\section{Inclusion and Exclusion Criteria}

Only randomized controlled trials (RCTs) comparing preoperative use of steroid in patients undergoing liver resection with no use of steroid were included in this review. Exclusion criteria were: (1) retrospective studies, case-control studies and cohort studies, (2) liver transplantation studies, and (3) studies that did not directly investigate IR injury.

\section{Data Extraction}

The following data were extracted independently by the same two authors, and disagreements were resolved by a third author (WW). Extracted data were: (1) study characteristics: first author, country, study design, publication year, and indications for liver resection; (2) patient characteristics: age, sex, number of patients in steroid group and control group, number of patients in each group divided according to Child-Pugh classification, and number of patients in each group divided based on underlying liver disease; (3) intraoperative data: operative time, hepatic ischemia time, intraoperative blood loss, method of vascular 
control, liver resection technique, number of major resection in each group; (4) postoperative data: total bilirubin (TB), C-reactive protein (CRP), interleukin (IL) 6, IL-10, alanine aminotransferase (ALT), aspartate aminotransferase (AST), postoperative hospital stay, and postoperative complications (overall complications, infection complications, wound complications, liver failure, bile leakage, and pleural effusion). Whenever relevant data were required, the corresponding authors were contacted via email. If contact was failed, data were measured from enlarged figures.

\section{Statistical Analysis}

All statistical analyses were performed using Review Manager (Version 5.3, Cochrane Collaboration, Oxford, England). The odds ratio (OR) and the mean difference (MD) with $95 \%$ confidence interval (CI) were used for dichotomous data and continuous data, respectively. Statistical analysis was performed with data mean and standard deviation for continuous data. If included studies provided only medians and data ranges, the means \pm standard deviation were calculated using the methods described by Hozo et al. (2005). Statistical heterogeneity was assessed by $\mathrm{I}^{2}$ value, an $\mathrm{I}^{2}$ value greater than $50 \%$ was regarded as significant heterogeneity (Higgins and Thompson, 2002). A random-effects model was selected in the case of significant heterogeneity. A $P$ value $<0.05$ was considered to be statistically significant. The results were illustrated by forest plots. The quality of included studies was evaluated using Cochrane Collaboration's Risk of Bias Tool (Higgins et al., 2011). Subgroup analyses were performed to seek potential heterogeneity source and identify subsets of patients who tended to benefit from steroid according to region (Japan, Italy, or Germany), method of vascular control (no Pringle maneuver, continuous or intermittent Pringle maneuver), sample size ( $>40$ or $<40$ ), and drug regimen (dosage of $30 \mathrm{mg} / \mathrm{kg}$ or dosage of $500 \mathrm{mg}$ ). Sensitivity analyses were also performed by omitting the included studies in turn to analyze the stability of the pooled results.

\section{RESULTS}

\section{Study Selection and Characteristics}

The search strategy identified 3,215 articles, of which 236 were duplicates, 2,952 were not relevant to the subject and 20 did not fulfill the inclusion criteria. Total seven articles considered for inclusion (Yamashita et al., 2001; Muratore et al., 2003; Aldrighetti et al., 2006; Pulitano et al., 2007b; Schmidt et al., 2007; Hayashi et al., 2011; Donadon et al., 2016). However, two studies (Aldrighetti et al., 2006; Pulitano et al., 2007b) came from the same institution, including a part of overlapping patients, more detailed study was included (Aldrighetti et al., 2006). Finally, six studies meet the inclusion criteria was included in this meta-analysis (Yamashita et al., 2001; Muratore et al., 2003; Aldrighetti et al., 2006; Schmidt et al., 2007; Hayashi et al., 2011; Donadon et al., 2016). Study selection process is shown in Figure 1 following PRISMA guidelines (Liberati et al., 2009). The publication time of these studies ranged from 2001 to 2016. Of the six included studies, three came from Italy, two from Japan, and one from Germany. A total 411 patients were included in this meta-analysis, of whom 206 were in the steroid group and 205 in the control group. Main characteristics of the included studies are summarized in Table 1. Characteristics of liver resection in the included studies are shown in Table 2.

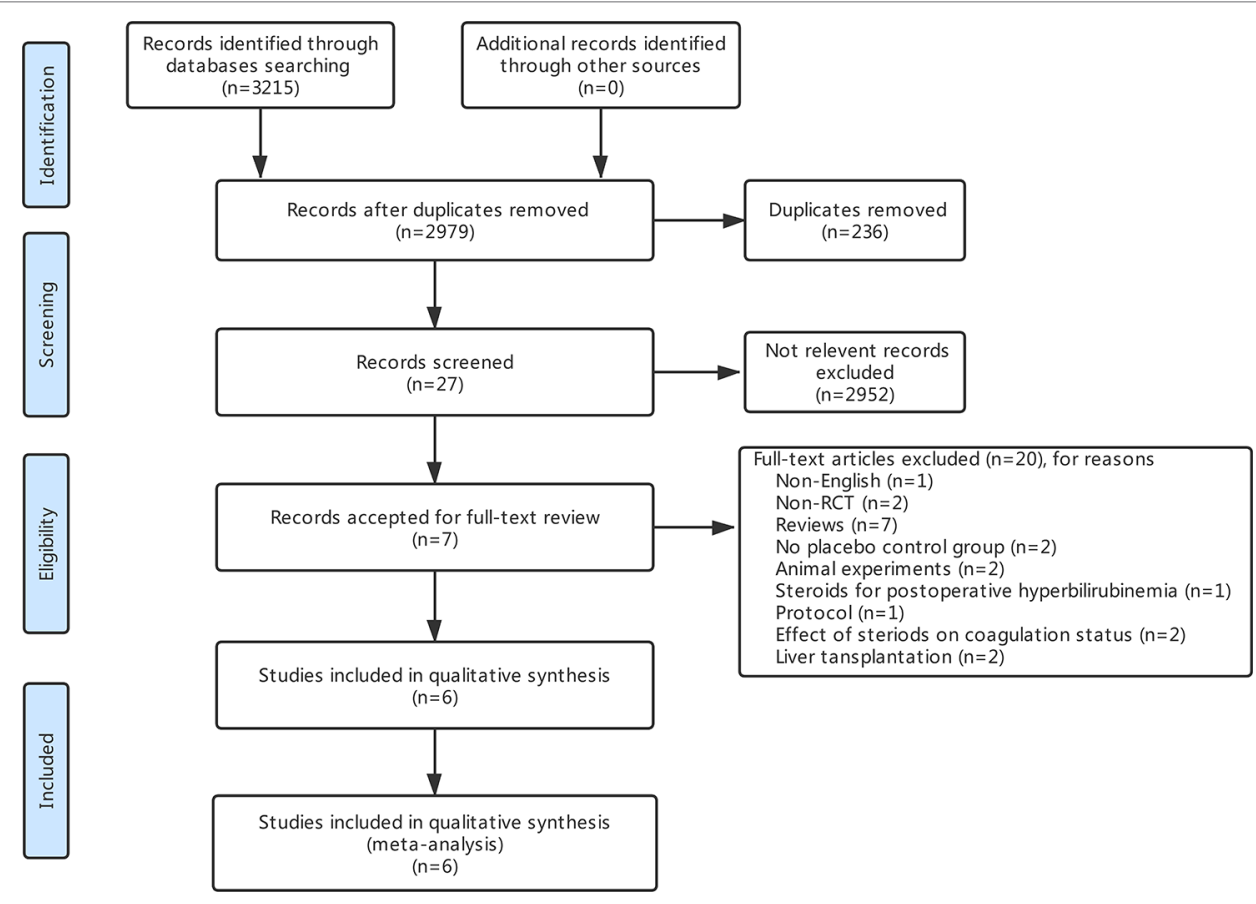

FIGURE 1 | Flow diagram of the study retrieval and selection process. 
TABLE 1 | Main characteristics of the included studies

\begin{tabular}{|c|c|c|c|c|c|c|c|c|c|c|c|c|c|}
\hline \multirow{3}{*}{$\begin{array}{l}\text { Author } \\
\text { Aldrighetti et al. }\end{array}$} & \multirow{3}{*}{$\begin{array}{l}\text { Year } \\
2006\end{array}$} & \multirow{3}{*}{$\begin{array}{l}\text { Country } \\
\text { Italy }\end{array}$} & \multirow{3}{*}{$\begin{array}{l}\begin{array}{l}\text { Study } \\
\text { design }\end{array} \\
\text { RCT }\end{array}$} & \multicolumn{2}{|c|}{ No. of patients } & \multicolumn{2}{|c|}{ Age (year) } & \multicolumn{2}{|c|}{ Gender, M/F } & \multirow{2}{*}{\multicolumn{2}{|c|}{$\begin{array}{l}\text { Child-Pugh } \\
\text { classification } \\
\text { (A/B/C) }\end{array}$}} & \multirow{3}{*}{$\begin{array}{l}\text { Steroid protocol } \\
\begin{array}{l}\text { MP } 500 \mathrm{mg} \text { before } \\
\text { anesthesia }\end{array}\end{array}$} & \multirow{3}{*}{$\begin{array}{l}\text { Outcome measure } \\
\begin{array}{l}\text { ALT, AST, TB, INR, IL-6, } \\
\text { complications, hospital } \\
\text { stay }\end{array}\end{array}$} \\
\hline & & & & \multirow{2}{*}{$\begin{array}{c}\text { Steroid } \\
36\end{array}$} & \multirow{2}{*}{$\begin{array}{c}\text { Control } \\
37\end{array}$} & \multirow{2}{*}{$\begin{array}{c}\text { Steroid } \\
\begin{array}{c}61.8(21-78) \\
a\end{array}\end{array}$} & \multirow{2}{*}{$\frac{\text { Control }}{63(31-85)^{\mathrm{a}}}$} & \multirow{2}{*}{$\begin{array}{l}\text { Steroid } \\
22 / 14\end{array}$} & \multirow{2}{*}{$\begin{array}{l}\text { Control } \\
23 / 14\end{array}$} & & & & \\
\hline & & & & & & & & & & $36 / 0 / 0$ & $37 / 0 / 0$ & & \\
\hline Donadon et al. & 2016 & Italy & $\mathrm{RCT}$ & 16 & 16 & $65(27-80)^{a}$ & $63(22-77)^{\mathrm{a}}$ & $10 / 6$ & $9 / 7$ & $N R$ & $N R$ & $\begin{array}{l}\text { MP } 500 \text { mg } 1 \mathrm{~h} \text { before liver } \\
\text { resection }\end{array}$ & $\begin{array}{l}\text { ALT, TB, complications, } \\
\text { hospital stay }\end{array}$ \\
\hline Hayashi et al. & 2011 & Japan & $\mathrm{RCT}$ & 102 & 98 & $69(39-81)^{a}$ & $70(35-72)^{\mathrm{a}}$ & $N R$ & NR & $99 / 3 / 0$ & $94 / 4 / 0$ & $\begin{array}{l}\text { HC } 500 \mathrm{mg} \text { before hepatic } \\
\text { pedicle clamping, } 300 \mathrm{mg} \\
\text { on POD } 1,200 \mathrm{mg} \text { on } \\
\text { POD 2, } 100 \mathrm{mg} \text { on POD } 3\end{array}$ & $\begin{array}{l}\text { ALT, AST, TB, INR, CRP, } \\
\text { IL-6, IL-10, complications, } \\
\text { hospital stay }\end{array}$ \\
\hline Muratore et al. & 2003 & Italy & $\mathrm{RCT}$ & 25 & 28 & $65.4 \pm 10.8^{b}$ & $64.1 \pm 11.7^{\mathrm{b}}$ & $17 / 8$ & $11 / 17$ & $N R$ & $N R$ & $\begin{array}{l}\text { MP } 30 \mathrm{mg} / \mathrm{kg} 0.5 \mathrm{~h} \text { before } \\
\text { liver resection }\end{array}$ & $\begin{array}{l}\text { ALT, AST, TB, PT, IL-6, } \\
\text { complications, hospital stay }\end{array}$ \\
\hline Schmidt et al. & 2007 & Germany & $\mathrm{RCT}$ & 10 & 10 & $57^{\circ}$ & $65^{\circ}$ & $3 / 7$ & $4 / 6$ & $N R$ & $N R$ & $\begin{array}{l}\text { MP } 30 \mathrm{mg} / \mathrm{kg} 1.5 \mathrm{~h} \text { before } \\
\text { surgery }\end{array}$ & $\begin{array}{l}\text { ALT, AST, TB, INR, IL-6, } \\
\text { IL-8, IL-10, TNF- } \alpha, \text { CRP, } \\
\text { complications, hospital } \\
\text { stay }\end{array}$ \\
\hline Yamashita et al. & 2001 & Japan & RCT & 17 & 16 & $60.3 \pm 1.8^{b}$ & $56.8 \pm 3.9^{b}$ & $13 / 4$ & $11 / 5$ & $N R$ & NR & $\begin{array}{l}\text { MP } 500 \mathrm{mg} 2 \mathrm{~h} \text { before } \\
\text { surgery }\end{array}$ & $\begin{array}{l}\text { ALT, AST, TB, PT, IL-6, } \\
\text { IL-10, CRP, complications, } \\
\text { hospital stay }\end{array}$ \\
\hline
\end{tabular}

a Data expressed as median (range); bdata are expressed as mean $\pm S D$; ${ }^{\circ}$ data are expressed as mean.

RCT, randomized controlled trial; MP, methylprednisolone; HC, hydrocortisone; ALT, alanine aminotransferase; AST, aspartate aminotransferase; INR, international normalized ratio; CRP, C-reactive protein; IL,

interleukin; TNF, tumor necrosis factor; PT, prothrombin time; NR, not reported.

TABLE 2 | Characteristics of liver resection of the included studies.

\begin{tabular}{|c|c|c|c|c|c|c|c|c|c|c|c|c|c|c|c|}
\hline \multirow[t]{2}{*}{ Author } & \multirow[t]{2}{*}{ Year } & \multicolumn{2}{|c|}{ Major resection } & \multirow[t]{2}{*}{$\begin{array}{l}\text { Vascular } \\
\text { control }\end{array}$} & \multirow[t]{2}{*}{$\begin{array}{l}\text { Resection } \\
\text { technique }\end{array}$} & \multicolumn{2}{|c|}{$\begin{array}{l}\text { Indication of surgery (HCC/ } \\
\text { MLT/CCC/LDLT/GC/others) }\end{array}$} & \multicolumn{2}{|c|}{ Operative time (min) } & \multicolumn{2}{|c|}{$\begin{array}{l}\text { Ischemia time (min) } \\
\text { Steroid Control }\end{array}$} & \multicolumn{2}{|c|}{ Blood loss (mL) } & \multicolumn{2}{|c|}{$\begin{array}{c}\text { Underlying liver } \\
\text { disease (normal/ } \\
\text { cirrhosis/steatosis) }\end{array}$} \\
\hline & & Steroid & Control & & & Steroid & Control & Steroid & Control & Steroid & Control & Steroid & Control & Steroid & Control \\
\hline Aldrighetti et al. & 2006 & 26 & 27 & $\begin{array}{l}\text { Intermittent } \\
\text { Pringle } \\
\text { maneuver }\end{array}$ & $\begin{array}{l}\text { Ultrasonic } \\
\text { dissector and } \\
\text { ultrasonic } \\
\text { scalpel }\end{array}$ & $14 / 14 / 4 / 0 / 0 / 4$ & $12 / 16 / 4 / 0 / 1 / 4$ & $408(240-460)^{\mathrm{a}}$ & $440(220-480)^{a}$ & $52.4(20-89)^{a}$ & $43(20-78)^{\mathrm{a}}$ & $621(350-720)^{\mathrm{a}}$ & $662(300-800)^{\mathrm{a}}$ & $18 / 14 / 4$ & $21 / 12 / 4$ \\
\hline Donadon et al. & 2016 & 7 & 5 & $\begin{array}{l}\text { Intermittent } \\
\text { Pringle } \\
\text { maneuver }\end{array}$ & $\begin{array}{l}\text { Crush } \\
\text { clamping }\end{array}$ & 6/6/4/0/0/0 & 2/12/0/0/0/2 & $383.5(235-546)^{\mathrm{a}}$ & $351(226-640)^{a}$ & $83(46-162)^{a}$ & $\begin{array}{c}80.5 \\
(35-168)^{\mathrm{a}}\end{array}$ & $275(100-1000)^{a}$ & $200(0-700)^{\mathrm{a}}$ & NR & NR \\
\hline Hayashi et al. & 2011 & 11 & 15 & $\begin{array}{l}\text { Intermittent } \\
\text { Pringle } \\
\text { maneuver }\end{array}$ & NR & 63/32/6/0/0/1 & $66 / 23 / 5 / 0 / 0 / 4$ & $330(165-834)^{\mathrm{a}}$ & $316(136-697)^{a}$ & $72(0-247)^{a}$ & $60(0-203)^{\mathrm{a}}$ & $324(5-1577)^{\mathrm{a}}$ & $257(10-1972)^{a}$ & NR & NR \\
\hline Muratore et al. & 2003 & 13 & 15 & $\begin{array}{l}\text { Continuous } \\
\text { Pringle } \\
\text { maneuver }\end{array}$ & $\begin{array}{l}\text { Ultrasonic } \\
\text { dissector }\end{array}$ & NR & NR & NR & NR & $41.4 \pm 15.9^{b}$ & $37.3 \pm 17.8^{b}$ & $322.8 \pm 261.4^{b}$ & $294.6 \pm 271.9^{b}$ & $8 / 10 / 7$ & $15 / 4 / 9$ \\
\hline Schmidt et al. & 2007 & 6 & 5 & No use & $\begin{array}{l}\text { Ultrasound } \\
\text { dissector }\end{array}$ & 2/4/0/0/0/4 & 1/4/2/0/0/3 & $222^{\circ}$ & $252^{\circ}$ & NR & NR & $340^{\circ}$ & $780^{\circ}$ & NR & NR \\
\hline Yamashita et al. & 2001 & 5 & 6 & $\begin{array}{l}\text { Continuous } \\
\text { Pringle } \\
\text { maneuver }\end{array}$ & NR & 13/0/0/4/0/0 & 8/3/1/4/0/0 & $338 \pm 87^{b}$ & $352 \pm 56^{\mathrm{b}}$ & NR & NR & $892 \pm 437^{b}$ & $822 \pm 220^{b}$ & NR & NR \\
\hline
\end{tabular}

aData expressed as median (range); ${ }^{\circ}$ data are expressed as mean $\pm S D$; c data are expressed as mean.

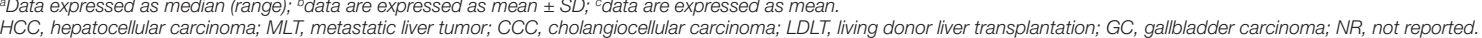




\section{Postoperative Complications}

Postoperative complications reported in the included studies are summarized in Table 3. There was no significant difference in the incidence of overall complications between the steroid group and the control group (OR, 0.57; 95\% CI, 0.27-1.17; $P=0.13$ ) (Figure 2A). In terms of specific complications, no significant difference was detected between the two groups in infection complications (OR, 0.95; 95\% CI, 0.13-6.95; $P=0.96$ ) (Figure 2B), wound complications (OR, 0.65; 95\% CI, 0.32-1.33; $P=0.24$ ) (Figure 2C), liver failure (OR, $0.41 ; 95 \% \mathrm{CI}, 0.10-1.64 ; P=0.21$ ) (Figure 2D), bile leakage (OR, 0.57; 95\% CI, 0.17-1.89; $P=0.36$ ) (Figure 2E), and pleural effusion (OR, 1.24; 95\% CI, $0.55-2.78 ; P=0.60)$ (Figure 2F). There were no postoperative deaths in all studies.

\section{Postoperative Liver Function}

The level of serum TB on postoperative day 1 (POD 1) was significantly decreased associated with the intervention of steroids (MD, $-0.54 ; 95 \% \mathrm{CI},-0.94$ to $-0.15 ; P=0.007$ ) (Figure 3A). There was no significant difference in the level of ALT (MD, $-69.39 ; 95 \% \mathrm{CI},-226.52$ to $87.75 ; P=0.39$ ) (Figure 3B) and AST (MD, -93.44 ; 95\% CI, -275.68 to $88.80 ; P=0.31)$ (Figure $3 \mathrm{C}$ ) on POD 1 between the steroid group and the control group.

\section{Postoperative Inflammatory Response}

Serum IL-6 level on POD 1 (MD, -57.98 ; 95\% CI, -73.04 to $-42.91 ; P<0.00001$ ) (Figure 4A) and CRP level on POD 3 (MD, -4.83 ; 95\% CI, -6.07 to $-3.59 ; P<0.00001$ ) (Figure 4B) were significantly reduced in the steroid group comparing to the control group. Compared with the control group, the level of early postoperative IL-10 was significant higher in the steroid group (MD, 17.89; 95\% CI, 3.89 to $31.89 ; P=0.01$ ) (Figure 4C).

\section{Hospital Stay}

For length of hospital stay, there was no statistically significant difference between the steroid group and the control group (MD, -0.75 ; $95 \% \mathrm{CI},-3.03$ to $1.53 ; P=0.52$ ) (Figure $4 \mathrm{D}$ ).

\section{Quality of the Included Studies}

The evaluation of the risk of bias for included studies is shown in Figure 5 according to the Cochrane Collaboration's Risk of Bias Tool. Due to a small number of included studies, the test power was insufficient and the symmetry was difficult to evaluate, funnel plot analysis was not carried out.

\section{Subgroup Analysis}

Subgroup analyses were conducted for overall complications (Figure 6), TB on POD 1 (Figure 7), and IL-6 on POD 1 (Figure 8) based on region, method of vascular control, sample size, and drug regimen. The summary of subgroup analyses are presented in Table 4.

\section{Subgroup Analysis of Overall Complications}

No significant change was detected in the subgroup analysis of overall complications, the results were consistent with the aforementioned outcome. However, low heterogeneity of overall complications was found in studies from Japan $\left(I^{2}=0\right)$, studies with continuous Pringle maneuver $\left(I^{2}=0\right)$, studies with small sample $\left(I^{2}=0\right)$, and studies with dosage of $30 \mathrm{mg} / \mathrm{kg}\left(I^{2}=0\right)$, indicating that region, method of vascular control, sample size, and drug regimen were potential sources of heterogeneity.

\section{Subgroup Analysis of TB on POD 1}

The difference of TB on POD 1 was not significant between the steroid group and the control group in studies with large sample or

TABLE 3 | Postoperative complications reported in the included studies.

\begin{tabular}{|c|c|c|c|c|c|c|c|c|c|c|c|c|}
\hline \multirow[t]{2}{*}{ Complications (n) } & \multicolumn{2}{|c|}{$\begin{array}{l}\text { Aldrighetti et al. } \\
\qquad(2006)\end{array}$} & \multicolumn{2}{|c|}{$\begin{array}{l}\text { Donadon et al. } \\
\qquad(2016)\end{array}$} & \multicolumn{2}{|c|}{$\begin{array}{l}\text { Hayashi et al. } \\
\text { (2011) }\end{array}$} & \multicolumn{2}{|c|}{$\begin{array}{l}\text { Muratore et al. } \\
\qquad(2003)\end{array}$} & \multicolumn{2}{|c|}{$\begin{array}{l}\text { Schmidt et al. } \\
\text { (2007) }\end{array}$} & \multicolumn{2}{|c|}{$\begin{array}{c}\text { Yamashita et al. } \\
(2001)\end{array}$} \\
\hline & SG & CG & SG & CG & SG & CG & SG & CG & SG & CG & SG & CG \\
\hline Infection complications & 2 & 8 & NR & NR & 16 & 5 & NR & NR & - & - & 1 & 1 \\
\hline Liver failure & 2 & 4 & NR & $\mathrm{NR}$ & 1 & 3 & NR & NR & - & - & - & - \\
\hline Bile leakage & 0 & 1 & NR & $\mathrm{NR}$ & 3 & 5 & NR & NR & 1 & 1 & - & - \\
\hline Ascites & - & - & NR & $\mathrm{NR}$ & - & - & NR & NR & - & - & 1 & 0 \\
\hline Wound complications & 0 & 2 & NR & NR & 13 & 15 & NR & NR & 0 & 1 & 0 & 1 \\
\hline Hemorrhage & 0 & 1 & NR & NR & - & - & NR & NR & - & - & - & - \\
\hline Cardiovascular & 0 & 3 & NR & NR & - & - & NR & NR & - & - & - & - \\
\hline Pleural effusion & 1 & 1 & NR & NR & 14 & 11 & NR & NR & - & - & - & - \\
\hline Bile duct stenosis & - & - & $N R$ & NR & - & - & NR & NR & 1 & 1 & - & - \\
\hline Reoperation & - & - & NR & $N R$ & 1 & 3 & NR & NR & - & - & - & - \\
\hline Atelectasis & - & - & NR & NR & 5 & 8 & NR & NR & - & - & - & - \\
\hline Side effect of steroids & - & - & NR & NR & - & - & NR & NR & - & - & - & - \\
\hline Death & - & - & NR & NR & - & - & NR & NR & - & - & - & - \\
\hline Total events & 5 & 20 & 3 & 2 & 53 & 50 & 7 & 12 & 2 & 3 & 2 & 2 \\
\hline Overall complications ${ }^{\star}$ & 5 & 20 & 3 & 2 & 41 & 42 & 7 & 12 & 2 & 3 & 2 & 2 \\
\hline
\end{tabular}

NR, not reported; SG, steroid group; CG, control group.

* Number of patients. 


\section{A}

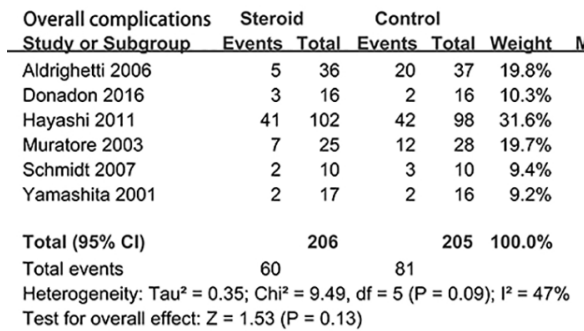

Odds Ratio Odds Ratio

M-H. Random. $95 \% \mathrm{Cl}$

$0.14[0.04,0.43]$

$1.62[0.23,11.26]$

$0.90[0.51,1.57]$

$0.52[0.16,1.64]$

$0.58[0.07,4.56]$

$0.93[0.12,7.55]$

$0.57[0.27,1.17]$

Test for overall effect: $Z=1.53(P=0.13)$

-H. Random. $95 \% \mathrm{Cl}$

B

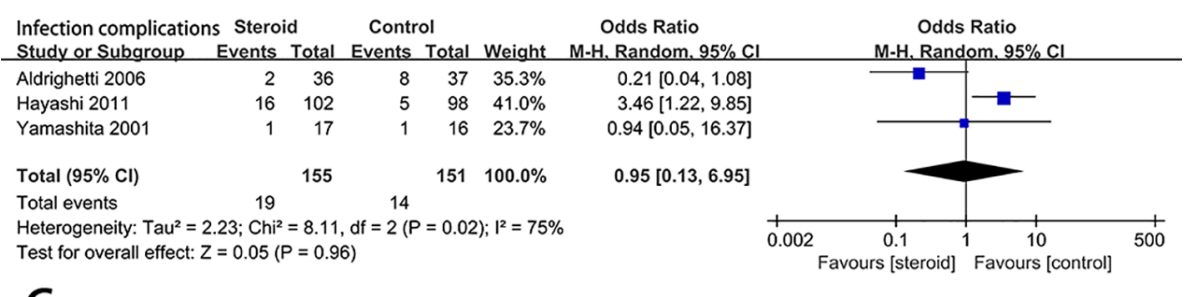

C

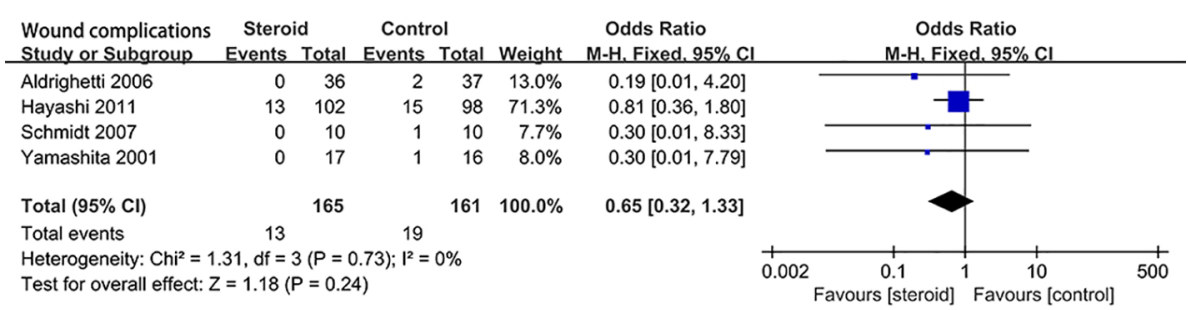

D

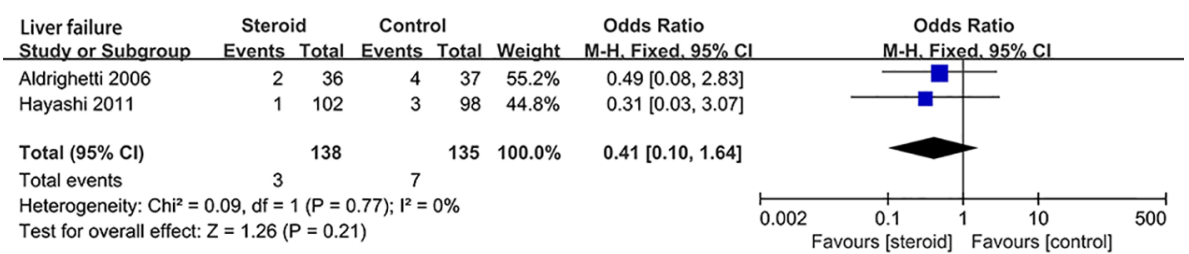

E

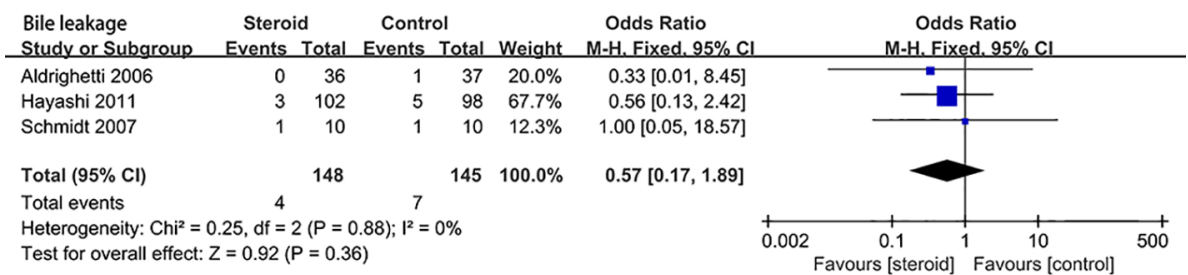

\section{F}

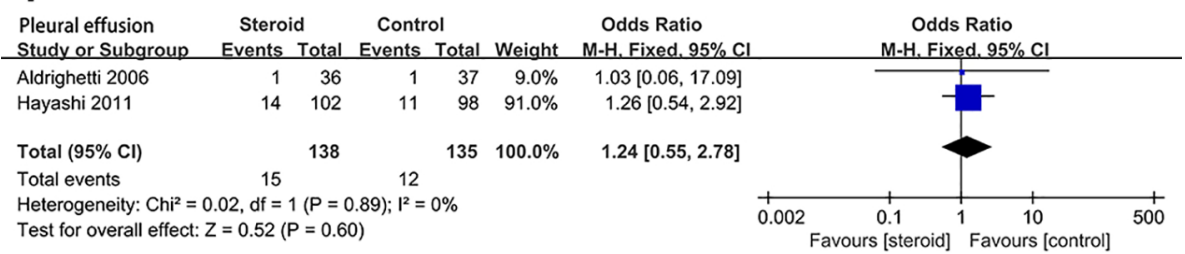

FIGURE 2 | The pooled results of comparison between the steroid group and the control group for postoperative complications illustrated by forest plots. The results were overall complications (A), infection complications (B), wound complications (C), liver failure (D), bile leakage (E), pleural effusion (F). 


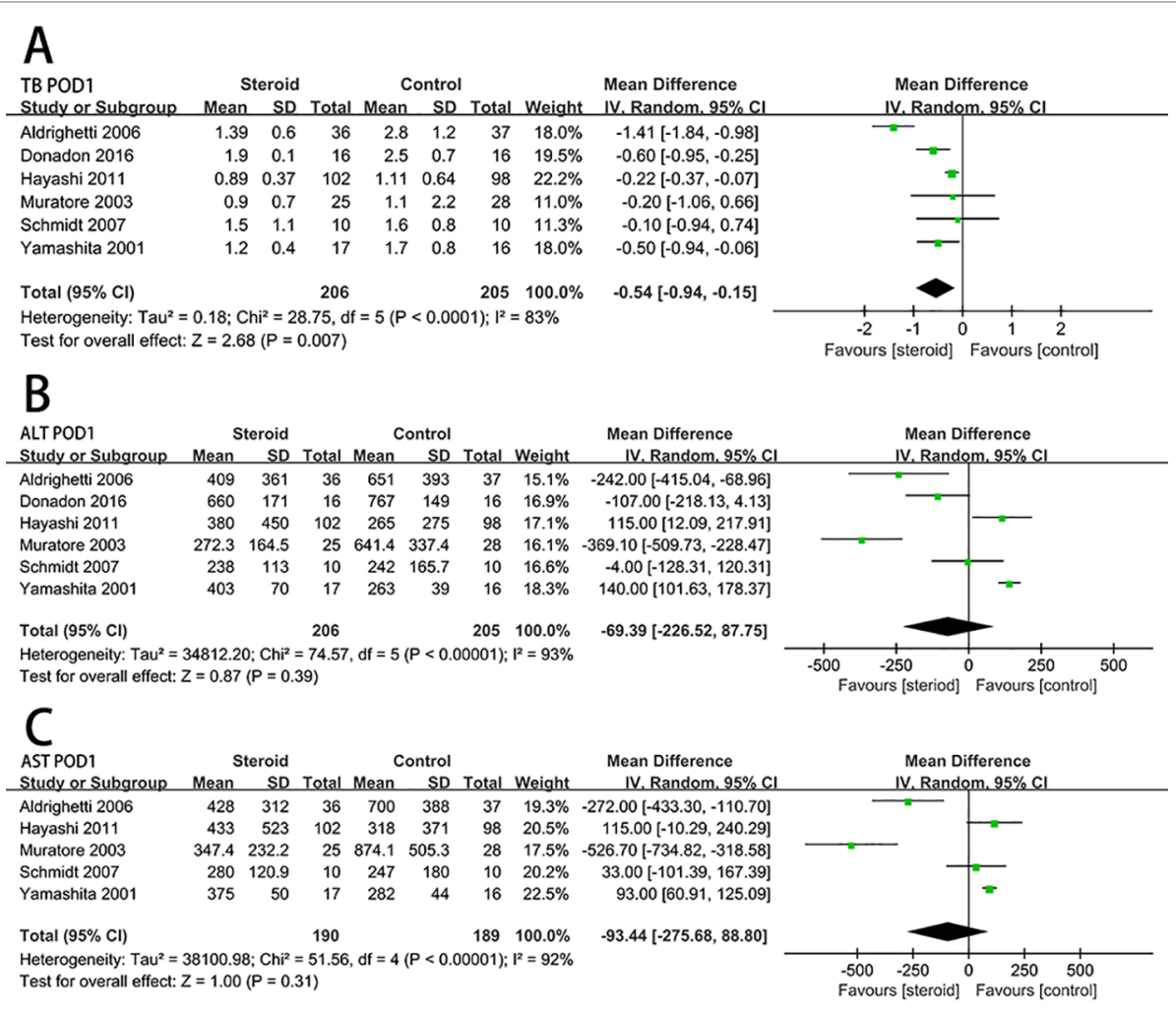

FIGURE 3 | The pooled results of comparison between the steroid group and the control group for postoperative liver function illustrated by forest plots. The results were TB on POD 1 (A), ALT on POD 1 (B), AST on POD 1 (C).

studies with dosage of $30 \mathrm{mg} / \mathrm{kg}$. Low heterogeneity of TB on POD 1 was detected in studies with continuous Pringle maneuver $\left(I^{2}=\right.$ 0 ), studies with small sample $\left(I^{2}=0\right)$, and studies with dosage of 30 $\mathrm{mg} / \mathrm{kg}\left(I^{2}=0\right)$, implying that method of vascular control, sample size, and drug regimen were potential sources of heterogeneity.

\section{Subgroup Analysis of IL-6 on POD 1}

The difference of IL- 6 on POD 1 was not significant between the two groups in studies from Italy or studies with continuous Pringle maneuver. Low heterogeneity of IL-6 on POD 1 was observed in studies with small sample $\left(I^{2}=0\right)$, suggesting that sample size was potential source of heterogeneity.

\section{Sensitivity Analysis}

Sensitivity analyses were also performed for overall complications, TB on POD 1, and IL-6 on POD 1, in which one study was removed at a time to assess the stability of the pooled results. Sensitivity analyses showed that pooled results did not change significantly with exclusion of the included studies in turn. The pooled results of overall complications, TB on POD 1 , and IL- 6 on POD 1 ranged from (OR, 0.46; 95\% CI, 0.19-1.12; $\left.I^{2}=37 \% ; P=0.09\right),\left(\mathrm{MD},-0.64 ; 95 \% \mathrm{CI},-1.08\right.$ to $-0.19 ; I^{2}=73 \%$; $P=0.005)$, (MD, $-71.11 ; 95 \% \mathrm{CI},-102.48$ to $-39.75 ; I^{2}=67 \%$; $P<0.00001)$ to (OR, 0.83; 95\% CI, 0.52-1.32; $\left.I^{2}=0 ; P=0.43\right)$, (MD, $-0.34 ; 95 \% \mathrm{CI},-0.52$ to $\left.-0.15 ; I^{2}=21 \% ; P=0.0004\right),(\mathrm{MD}$, $-53.03 ; 95 \% \mathrm{CI},-62.65$ to $\left.-43.41 ; I^{2}=30 \% ; P<0.00001\right)$.

\section{DISCUSSION}

In the present study, we performed a meta-analysis of preoperative administration of steroid in liver resection, demonstrating that steroid can promote the recovery of liver function and inhibit the inflammatory response without increasing postoperative complications after hepatectomy.

Serum TB is an important clinical parameter for postoperative liver dysfunction and also a critical prognosis relevant factor. The level of $\mathrm{TB}$ on POD 1 was significantly decreased associated with the use of steroid. The lower TB level in steroid group might be the result of a faster recovery of the liver. However, for the level of ALT and AST on POD 1, no statistical difference was detected between the steroid group and the control group according to the pooled results. This may be caused by different composition of patients in each included study. The study by Muratore et al. ( 2003) indicates that in patients with chronic liver diseases and AST and ALT levels on POD 1 were significantly lower in the steroid group than the control group. Nevertheless, in patients with normal liver, no statistical difference was found. Hence, the patients with chronic liver diseases may benefit more from preoperative administration of steroid and the steroid should be more often implemented in these patients.

As one of the most vital organs, the liver plays an important role in metabolic, secretory, and endocrine, which producing 


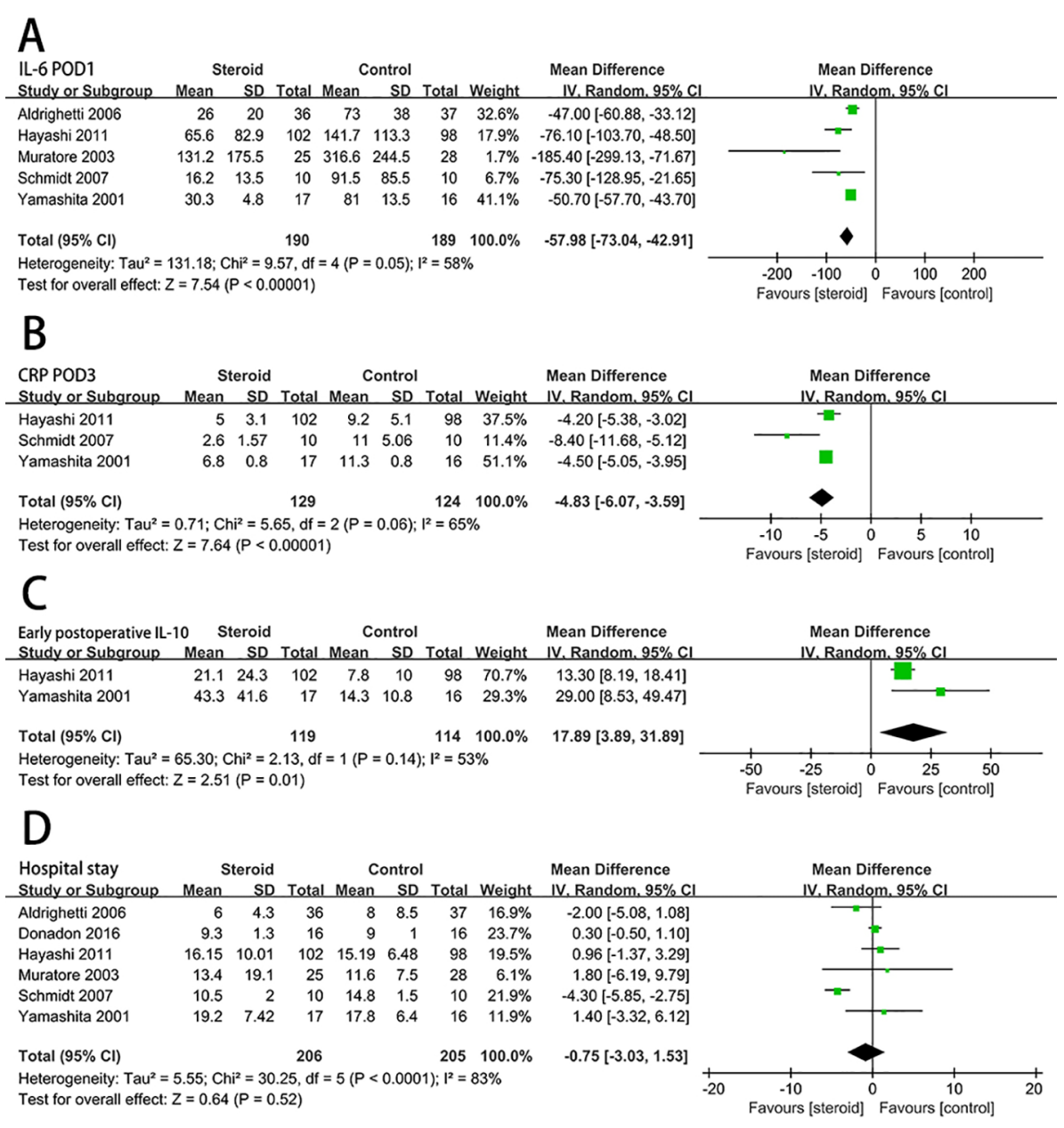

FIGURE 4 | The pooled results of comparison between the steroid group and the control group for postoperative inflammatory response and length of hospital stay illustrated by forest plots. The results were IL-6 on POD 1 (A), CRP on POD 3 (B), early postoperative IL-10 (C), length of hospital stay (D).

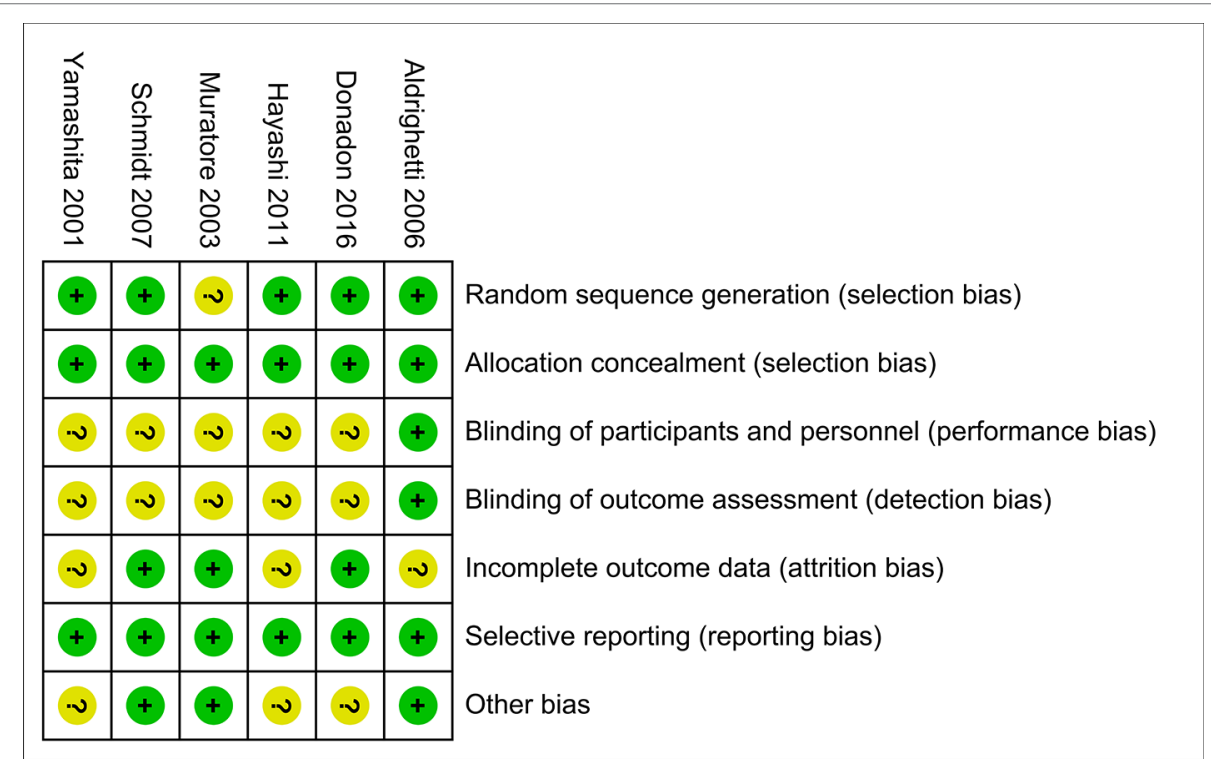

FIGURE 5 | Risk of bias summary. Dash sign: high risk of bias; plus sign: low risk of bias; question mark sign: unclear risk of bias. 


\section{A}

Steroid Control Odds Ratio

Study or Subgroup Events Total Events Total Weight $\mathrm{M}-\mathrm{H}$. Random, $95 \% \mathrm{Cl}$

1.2.1 Japan

Hayashi 2011

Yamashita 2001

$41 \quad 102$

$42 \quad 98 \quad 31.6 \%$

$0.90[0.51,1.57]$

Subtotal $(95 \% \mathrm{Cl})$

217

$2 \quad 16 \quad 9.2 \%$

$0.93[0.12,7.55]$

Total events

43

44

Heterogeneity: $\mathrm{Tau}^{2}=0.00 ; \mathrm{Chi}^{2}=0.00, \mathrm{df}=1(\mathrm{P}=0.97) ; \mathrm{I}^{2}=0 \%$

Test for overall effect: $Z=0.39(P=0.70)$

1.2.2 Italy

Aldrighetti 2006

Donadon 2016

Muratore 2003

Subtotal $(95 \% \mathrm{Cl})$

Total events

$\begin{array}{lllll}5 & 36 & 20 & 37 & 19.8 \%\end{array}$

Heterogeneity: $\mathrm{Tau}^{2}=0.81 ; \mathrm{Chi}^{2}=5.41, \mathrm{df}=2(\mathrm{P}=0.07) ; \mathrm{I}^{2}=63 \%$

Test for overall effect: $Z=1.34(P=0.18)$

1.2.3 Germany

Schmidt 2007

Subtotal $(95 \% \mathrm{Cl})$

Total events

210

10

2

Heterogeneity: Not applicable

Test for overall effect: $Z=0.51(P=0.61)$

Total $(95 \% \mathrm{Cl})$

$60 \quad 206 \quad 81$

Total events

$205100.0 \%$

Heterogeneity: $\mathrm{Tau}^{2}=0.35 ; \mathrm{Chi}^{2}=9.49, \mathrm{df}=5(\mathrm{P}=0.09) ; \mathrm{I}^{2}=47 \%$

Test for overall effect: $Z=1.53(P=0.13)$

Test for subaroun differences: $\mathrm{Chi}^{2}=1.27 . \mathrm{df}=2(\mathrm{P}=0.53) . \mathrm{I}^{2}=0 \%$
$0.14[0.04,0.43]$

$1.62[0.23,11.26]$

$0.52[0.16,1.64]$

$0.41[0.11,1.50]$
$0.58[0.07,4.56]$

$0.58[0.07,4.56]$

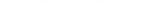

$0.57[0.27,1.17]$

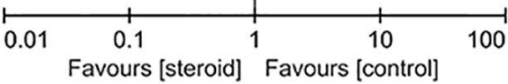

Odds Ratio

M-H. Random. $95 \%$ C

\section{B}

Steroid

Control

Study or Subgroup Events Total Events Total Weight $\mathrm{M}-\mathrm{H}$. Random. $95 \% \mathrm{Cl}$ 1.4.1 Continuous Pringle maneuver

Muratore 2003

Yamashita 2001

Subtotal $(95 \% \mathrm{Cl})$

$\begin{array}{ll}7 & 25 \\ 2 & 17\end{array}$

\section{5}

$12 \quad 28 \quad 19.7 \%$

$2 \quad 16 \quad 9.2 \%$

$44 \quad 28.9 \%$

Total events

9

14

Heterogeneity: $\mathrm{Tau}^{2}=0.00 ; \mathrm{Chi}^{2}=0.23, \mathrm{df}=1(\mathrm{P}=0.63) ; \mathrm{I}^{2}=0 \%$

Test for overall effect: $Z=1.01(P=0.31)$

1.4.2 Intermittent Pringle maneuver

$\begin{array}{lrrrrr}\text { Aldrighetti } 2006 & 5 & 36 & 20 & 37 & 19.8 \% \\ \text { Donadon } 2016 & 3 & 16 & 2 & 16 & 10.3 \% \\ \text { Hayashi } 2011 & 41 & 102 & 42 & 98 & 31.6 \% \\ \text { Subtotal }(95 \% \mathrm{CI}) & & 154 & & 151 & 61.6 \% \\ \text { Total events } & 49 & & 64 & & \end{array}$

Total events $\mathrm{Tau}^{2}=1.14 ; \mathrm{Chi}^{2}=9.23, \mathrm{df}=2(\mathrm{P}=0.010) ; \mathrm{I}^{2}=78 \%$

Test for overall effect: $Z=0.86(P=0.39)$

1.4.3 No Pringle maneuver

Schmidt 2007

Subtotal $(95 \% \mathrm{Cl})$

$\begin{array}{lllll}2 & 10 & 3 & 10 & 9.4 \% \\ & 10 & & 10 & 9.4 \% \\ 2 & & 3 & & \end{array}$

Total events

le

Test for overall effect: $Z=0.51(P=0.61)$

Total $(95 \% \mathrm{Cl})$

Total events

206

Heterogeneity: $\mathrm{Tau}^{2}=0.35 ; \mathrm{Chi}^{2}=9.49, \mathrm{df}=5(\mathrm{P}=0.09) ; \mathrm{I}^{2}=47 \%$

Test for overall effect: $Z=1.53(P=0.13)$

Test for subaroun differences: $\mathrm{Ch}^{2}=0.01$. df $=2(P=0.99) . \mathrm{I}^{2}=0 \%$

Odds Ratio

$0.52[0.16,1.64]$

$0.93[0.12,7.55]$

$0.59[0.22,1.63]$

$0.14[0.04,0.43]$

$1.62[0.23,11.26]$

$0.90[0.51,1.57]$

$0.54[0.13,2.19]$

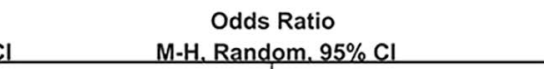

M-H. Random. $95 \%$ Cl

$0.58[0.07,4.56]$

$0.58[0.07,4.56]$

$0.57[0.27,1.17]$
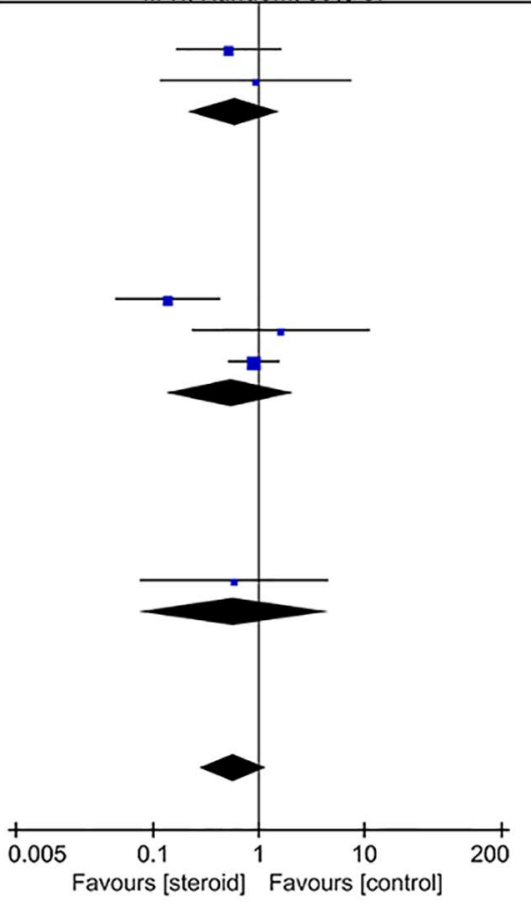

FIGURE 6 | Continued 


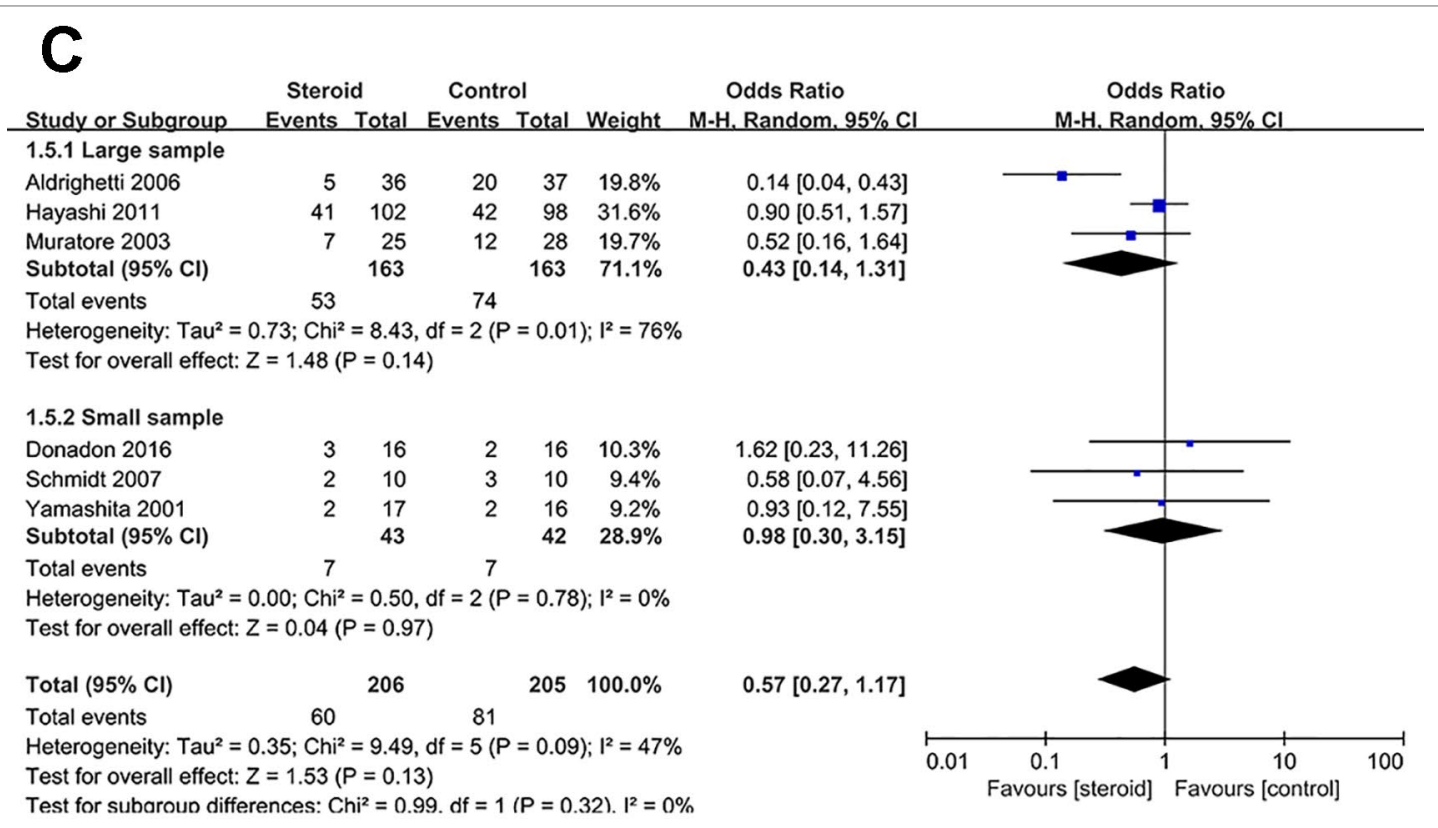

D

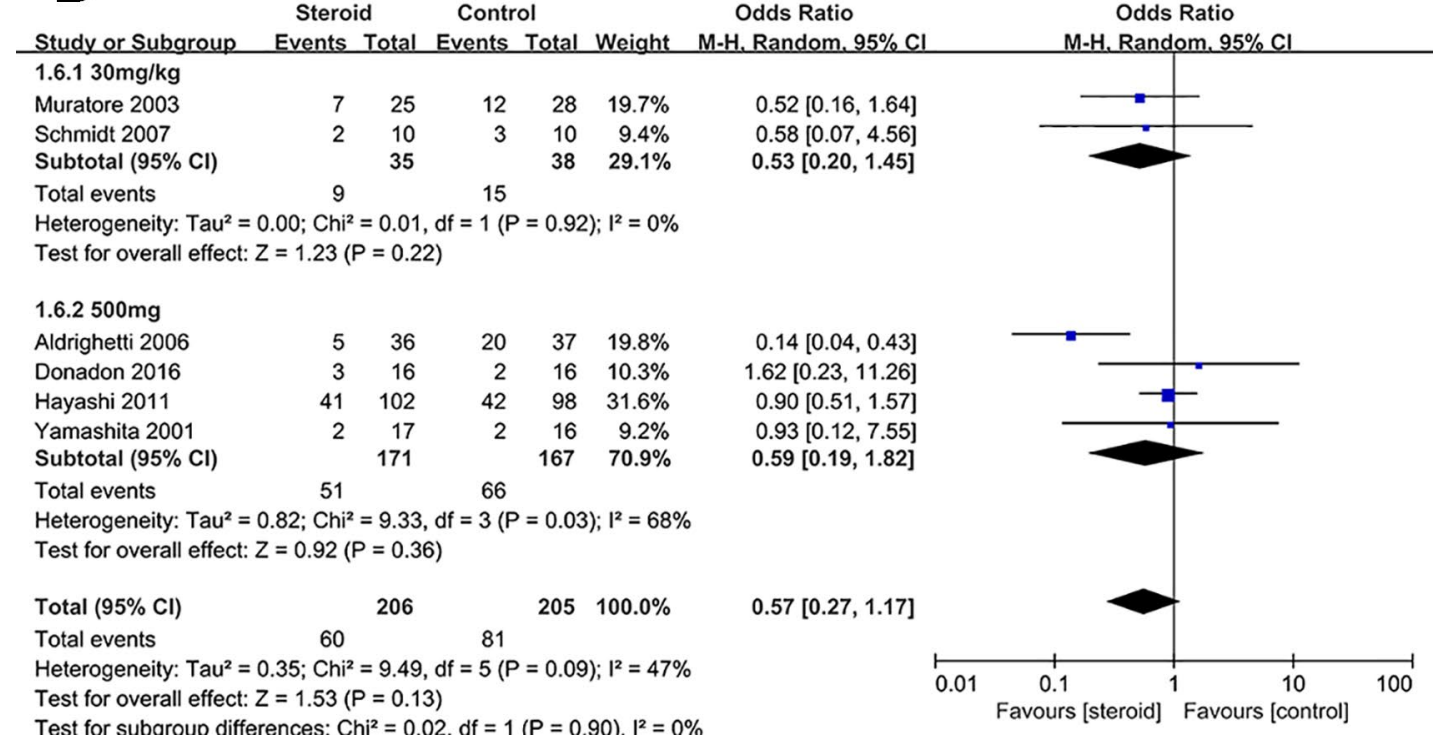

FIGURE 6 | Subgroup analysis of overall complications stratified by region (A), method of vascular control (B), sample size (C), and drug regimen (D).

inflammatory factors, modifying coagulation balance, and regulating protein metabolism (Berger et al., 1997). Cytokines released from stimulated macrophages and monocytes after liver resection, this reaction is called the hepatic acute response. In the acute response, IL- 6 acts as a critical modulator of the inflammation, not only influencing B-lymphocytes and T-lymphocytes, but inducing the production of acute-phase proteins in the liver, such as CRP, antiproteinases, and fibrinogen (Menger and Vollmar, 2004). Elevated blood cytokines can increase the risk of postoperative complications (Kimura et al.,
2006), therefore treatments to limit the cytokine response is needed. With the administration of steroid, IL-6, and CRP were significantly suppressed in the steroid group comparing to the control group. Previous research showed that the release of IL-6 is associated with the extent of liver resection, duration of operation, and volume of blood loss (Biffl et al., 1996). And the two included studies (Aldrighetti et al., 2006; Donadon et al., 2016) demonstrated that protective effects of preoperative steroid administration were more conspicuous in patients with larger resection volume and longer ischemic time. In liver resection, 

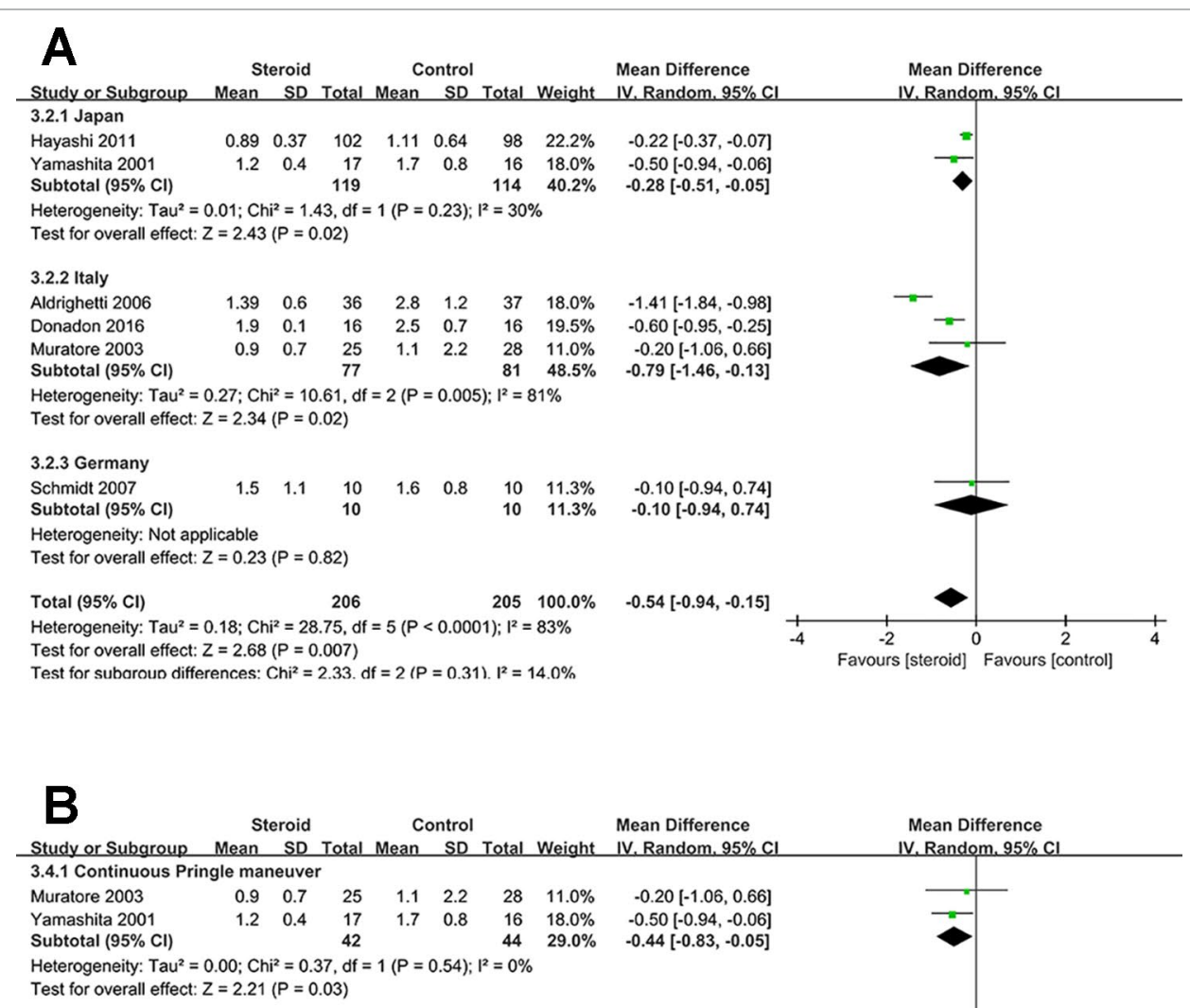

3.4.2 Itermittent Pringle maneuver

\begin{tabular}{|c|c|c|c|c|c|c|c|c|}
\hline Aldrighetti 2006 & 1.39 & 0.6 & 36 & 2.8 & 1.2 & 37 & $18.0 \%$ & $-1.41[-1.84,-0.98]$ \\
\hline Donadon 2016 & 1.9 & 0.1 & 16 & 2.5 & 0.7 & 16 & $19.5 \%$ & $-0.60[-0.95,-0.25]$ \\
\hline $\begin{array}{l}\text { Hayashi } 2011 \\
\text { Subtotal }(95 \% \text { Cl) }\end{array}$ & 0.89 & 0.37 & $\begin{array}{l}102 \\
154\end{array}$ & 1.11 & 0.64 & $\begin{array}{r}98 \\
151\end{array}$ & $\begin{array}{l}22.2 \% \\
59.8 \%\end{array}$ & $\begin{array}{r}-0.22[-0.37,-0.07] \\
-0.72[-1.36,-0.07]\end{array}$ \\
\hline
\end{tabular}

Test for overall effect: $Z=2.18(P=0.03)$

3.4.3 No Pringle maneuver

$\begin{array}{lllllllll}\text { Schmidt } 2007 & 1.5 & 1.1 & 10 & 1.6 & 0.8 & 10 & 11.3 \% & -0.10[-0.94,0.74] \\ \text { Subtotal }(95 \% \mathrm{Cl}) & & & 10 & & & 10 & 11.3 \% & -0.10[-0.94,0.74] \\ \text { Heterogeneity: Not applicable } & & & & & & & \end{array}$

Total $(95 \% \mathrm{Cl}) \quad 206 \quad 205 \quad 100.0 \% \quad-0.54[-0.94,-0.15]$

Heterogeneity: $\mathrm{Tau}^{2}=0.18 ; \mathrm{Chi}^{2}=28.75, \mathrm{df}=5(\mathrm{P}<0.0001) ; \mathrm{I}^{2}=83 \%$

Test for overall effect: $Z=2.68(P=0.007)$

Test for subarouo differences: $\mathrm{Chi}^{2}=1.32 . \mathrm{df}=2(\mathrm{P}=0.52) . \mathrm{I}^{2}=0 \%$

Mean Difference IV. Random. $95 \% \mathrm{C}$

Cl

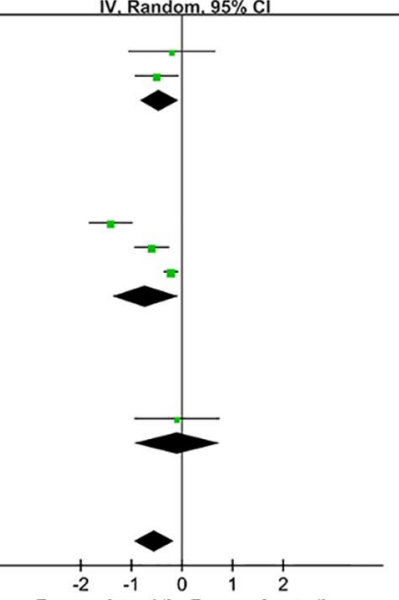

Favours [steroid] Favours [control]

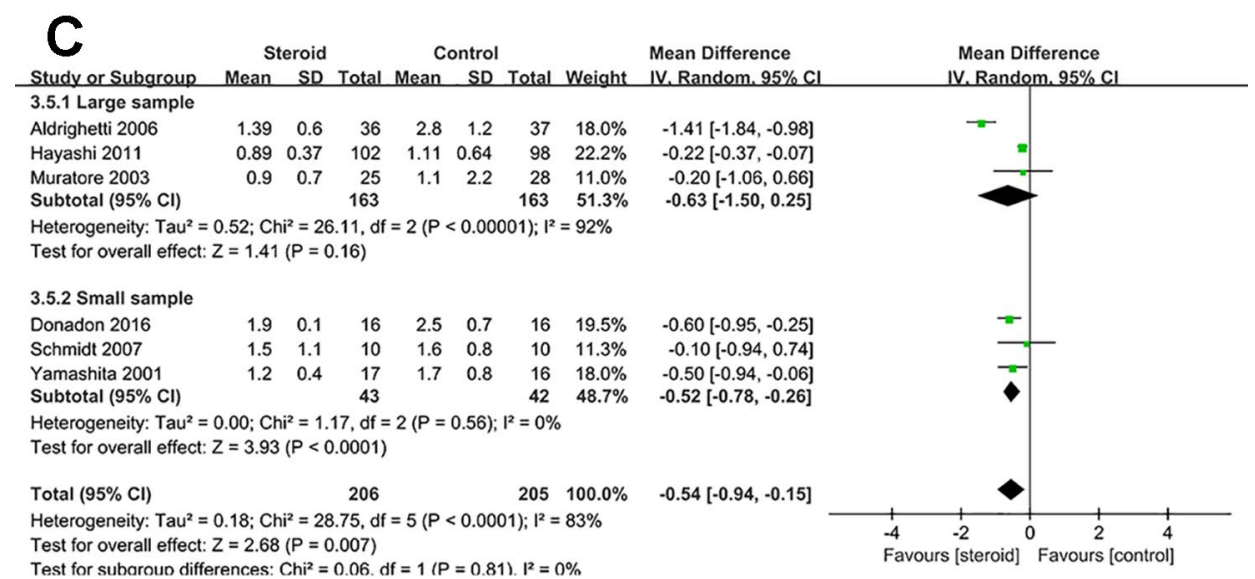

FIGURE 7 | Continued 


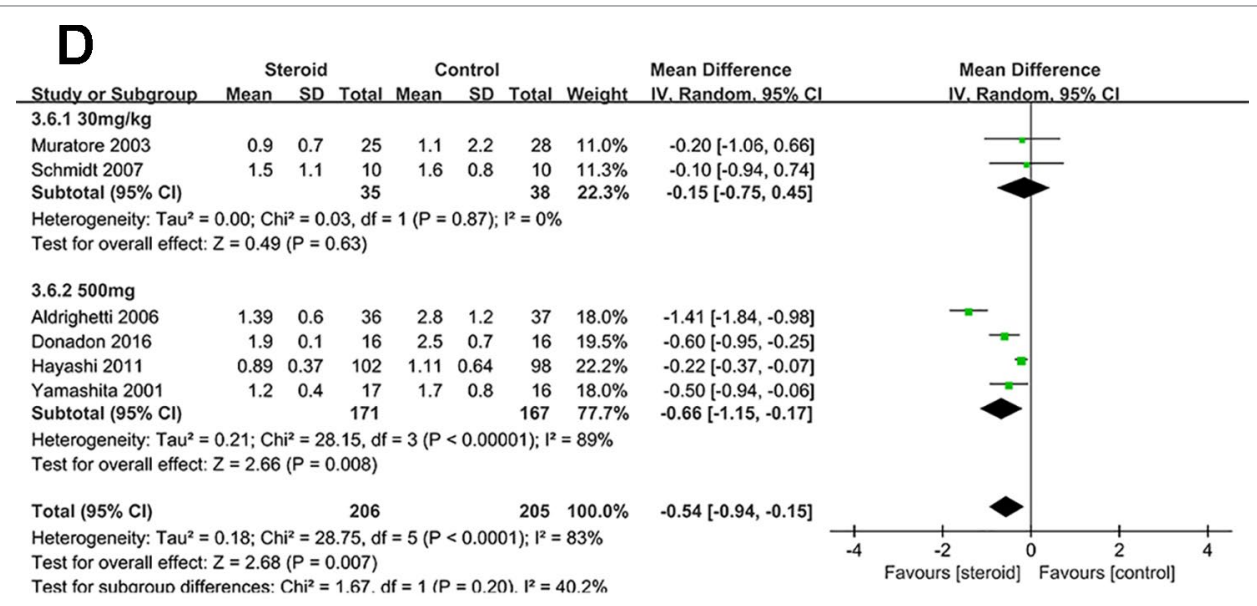

FIGURE 7 | Subgroup analysis of TB on POD 1 stratified by region (A), method of vascular control (B), sample size (C), and drug regimen (D).

the release of IL-6 is augmented by the use of Pringle maneuver, owing to the IR injury. Both continuous and intermittent Pringle maneuver were used in the included studies. However, the subgroup analysis of IL- 6 on POD 1 demonstrated that steroid can lead to a better outcome in studies with intermittent Pringle maneuver. IL-10 is a potent anti-inflammatory cytokine produced primarily by activated macrophages after liver surgery, it inhibits the release of pro-inflammatory cytokines and therefore tends to down-regulate the inflammatory reaction (Jerin et al., 2003). In this meta-analysis, use of the steroid was relevant to a significant increase of serum IL-10 level in early postoperative period. Consequently, maintaining the balance of pro- and antiinflammatory cytokines is a key factor to the recovery of patients undergoing liver surgery.

Prophylactic administration of steroid may potentially induce unnecessary side effects, such as postoperative infection, delayed wound healing, impaired liver regeneration. However, our pooled results indicated that preoperative use of steroid have no effect on the incidence of overall complications between the steroid group and the control group. In terms of specific complications, steroid also does not increase the incidence of infection complications, wound complications, liver failure, bile leakage, and pleural effusion. Besides, the subgroup analyses of overall complications suggested similar results. One (Aldrighetti et al., 2006) of the included studies reported that the infective complications were more frequent in the control group than the steroid group, yet other studies demonstrated no statistical difference was found between the two groups. This result was seemly paradoxical, however, Yamashita et al. (Yamashita et al., 2001) previously reported that preoperative use of steroid can decrease the serum level of immunosuppressive antigen and the positive rate of serum candida antigen, a marker of bacterial translocation. And similar findings were reported in esophagectomy (Shimada et al., 2000). Takeda et al. (Takeda et al., 2002) previously proposed the non regeneration type liver failure was mainly induced by severe IR injury after hepatectomy based on histological findings. And some literature reported that the overproduction of IL-6 during IR injury may inhibit liver regeneration (Wustefeld et al., 2000). Steroid can suppress IL-6 production, therefore, preoperative administration of steroid may have a positive effect on liver failure after liver resection. Though this meta-analysis showed that no significant difference was detected in the incidence of liver failure between the two groups. Despite great technical advances, bile leakage after liver resection remains a main postoperative complication. A previous study reported that immunosuppression may repress cholangiocyte regeneration by inhibiting signal transducer and activator of transcription 3 activation in a rat liver transplantation model (Chen et al., 2010). So far, no research show any available evidence about the effect of steroids on cholangiocyte regeneration. The pooled result of our metaanalysis indicated that there was no significant difference in bile leakage between the two groups.

Long-term follow-up is required for these patients after liver resection, because there are some concerns about the risk of tumor recurrence may cause by the anti-inflammatory effect of steroid. Recently, Ogasawara et al. (2017) reported that prophylactic administration of steroid in patients undergoing transcatheter arterial chemoembolization can achieve a greater overall complete response rate than control group. This result indicated that a short-term administration of steroid did not significantly affect tumor treatment. But more research is needed to solve this issue.

Some limitations existed in this meta-analysis. First, most of the studies included in this meta-analysis were relatively small sample sizes and lack of long-term follow-up data. Large sample size RCTs with long-term follow-up are urgently needed in the future. Second, postoperative complications were vital parameters to evaluate the safety of preoperative steroid administration, but only four studies reported specific complications. Third, some date were extracted from 


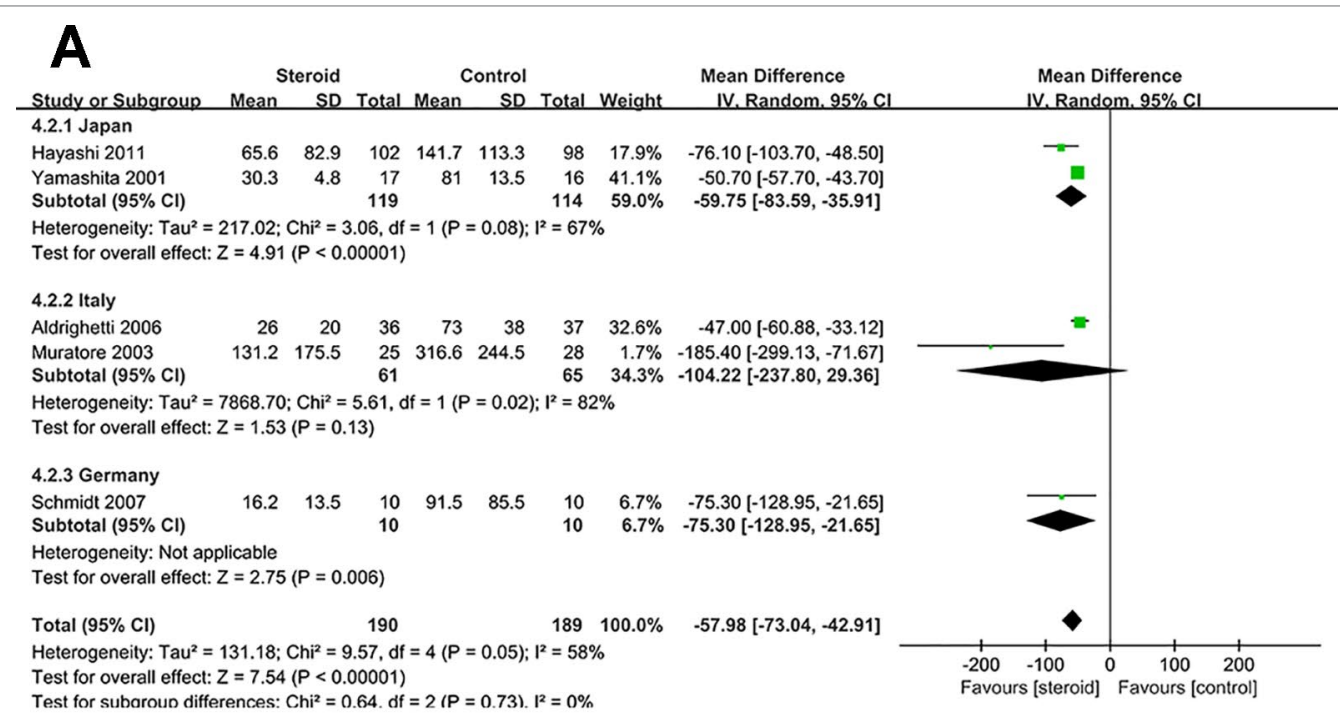

\section{B}

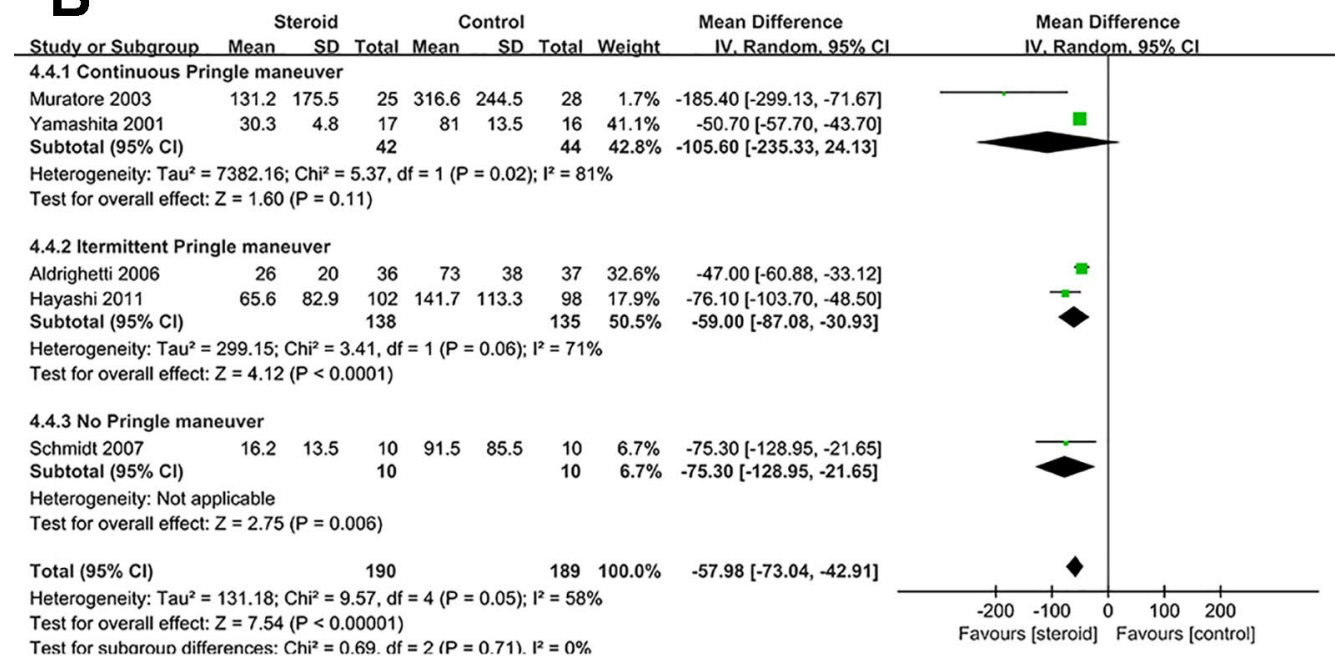

Test for subaroun differences: $\mathrm{Chi}^{2}=0.69$. of $=2(\mathrm{P}=0.71) . \mathrm{I}^{2}=0 \%$

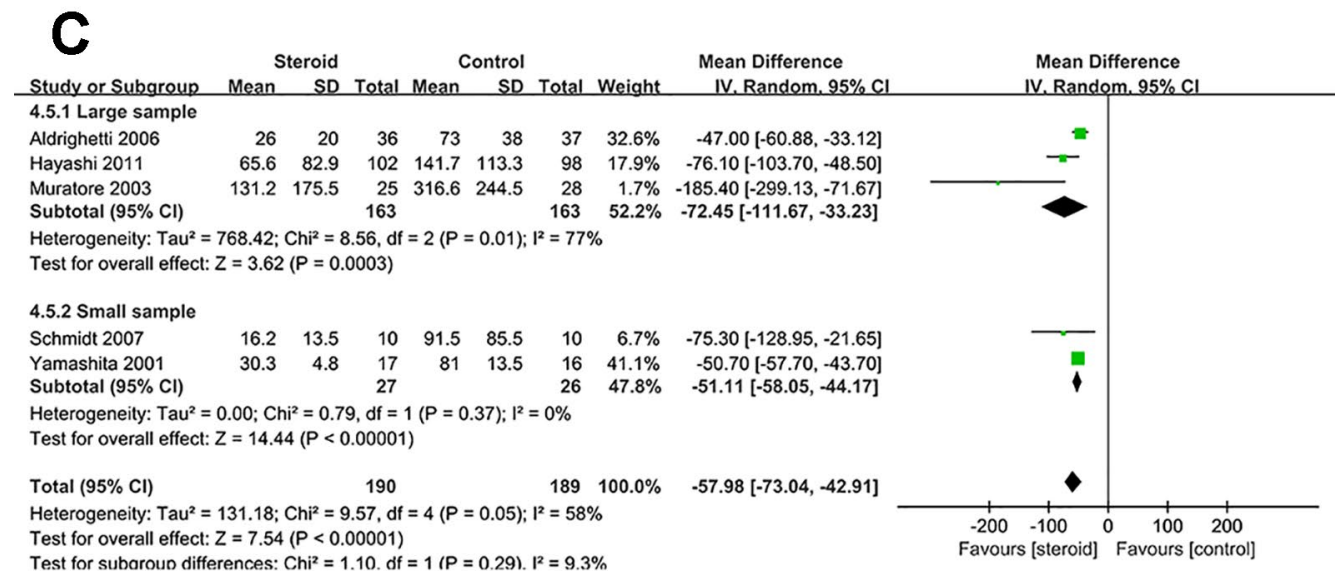

FIGURE 8 | Continued 


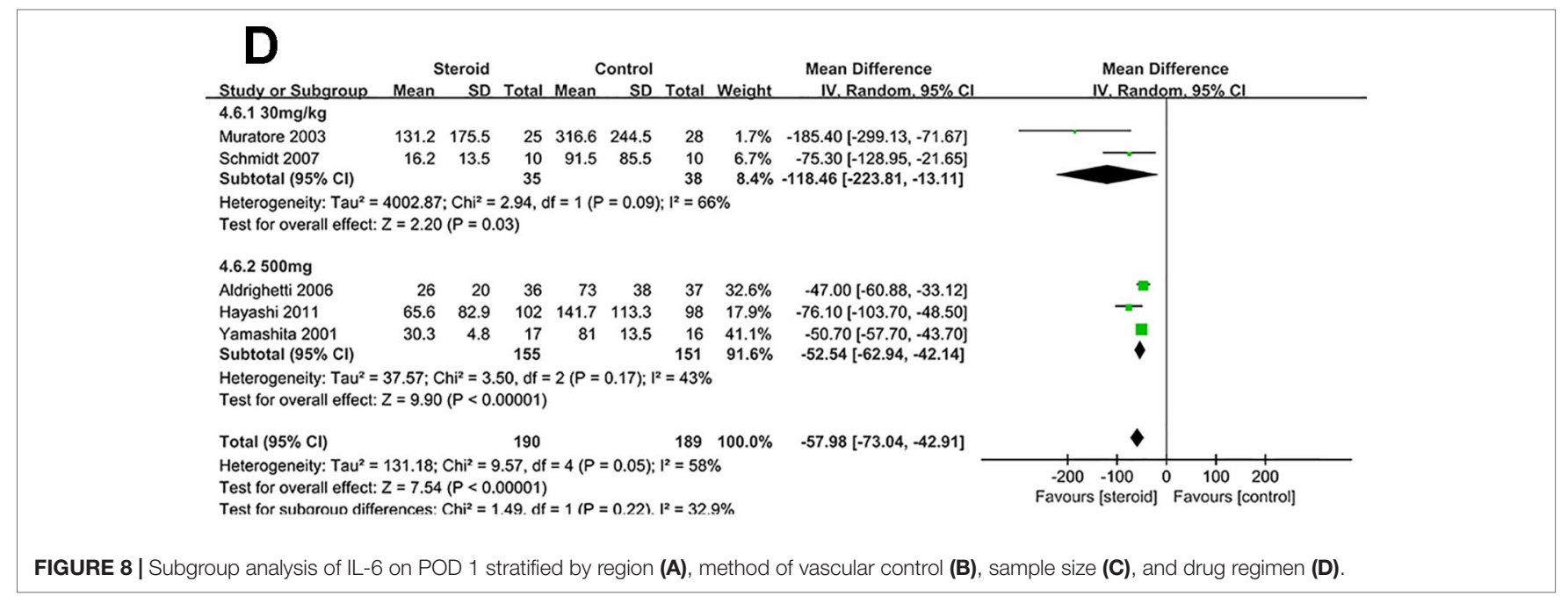

TABLE 4 | Summary of the subgroup analysis.

\begin{tabular}{|c|c|c|c|c|c|c|}
\hline Outcome & Subgroup & $\begin{array}{l}\text { No. of } \\
\text { studies }\end{array}$ & MD/OR (95\% Cl) & $\begin{array}{l}P \text { value } \\
\text { for overall } \\
\text { effect }\end{array}$ & $\begin{array}{c}\mathrm{I}^{2} \\
\text { value }\end{array}$ & $\begin{array}{c}\mathrm{P} \text { value for } \\
\text { heterogeneity }\end{array}$ \\
\hline & Studies from Italy & 3 & $0.41(0.11,1.50)$ & 0.18 & $63 \%$ & 0.07 \\
\hline & Studies from Germany & 1 & $0.58(0.07,4.56)$ & 0.61 & - & - \\
\hline & Studies with continuous Pringle maneuver & 2 & $0.59(0.22,1.63)$ & 0.31 & 0 & 0.63 \\
\hline & Studies with intermittent Pringle maneuver & 3 & $0.54(0.13,2.19)$ & 0.39 & $78 \%$ & 0.010 \\
\hline & Studies with small sample $(<40)$ & 3 & $0.98(0.30,3.15)$ & 0.97 & 0 & 0.78 \\
\hline & Studies with dosage of $30 \mathrm{mg} / \mathrm{kg}$ & 2 & $0.53(0.20,1.45)$ & 0.22 & 0 & 0.92 \\
\hline & Studies with dosage of $500 \mathrm{mg}$ & 4 & $0.59(0.19,1.82)$ & 0.36 & $68 \%$ & 0.03 \\
\hline \multirow[t]{6}{*}{ TB on POD 1} & Studies from Japan & 2 & $-0.28(-0.51,-0.05)$ & 0.02 & $30 \%$ & 0.23 \\
\hline & Studies from Italy & 3 & $-0.79(-1.46,-0.13)$ & 0.02 & $81 \%$ & 0.005 \\
\hline & Studies from Germany & 1 & $-0.10(-0.94,0.74)$ & 0.82 & - & - \\
\hline & Studies with small sample $(<40)$ & 3 & $-0.52(-0.78,-0.26)$ & $P<0.0001$ & 0 & 0.56 \\
\hline & Studies with dosage of $30 \mathrm{mg} / \mathrm{kg}$ & 2 & $-0.15(-0.75,0.45)$ & 0.63 & 0 & 0.87 \\
\hline & Studies with dosage of $500 \mathrm{mg}$ & 4 & $-0.66(-1.15,-0.17)$ & 0.008 & $89 \%$ & $P<0.00001$ \\
\hline \multirow[t]{10}{*}{ IL-6 on POD 1} & Studies from Japan & 2 & $-59.75(-83.59,-35.91)$ & $P<0.00001$ & $67 \%$ & 0.08 \\
\hline & Studies from Italy & 2 & $-104.22(-237.80,29.36)$ & 0.13 & $82 \%$ & 0.02 \\
\hline & Studies from Germany & 1 & $-75.30(-128.95,-21.65)$ & 0.006 & - & - \\
\hline & Studies with continuous Pringle maneuver & 2 & $-105.60(-235.33,24.13)$ & 0.11 & $81 \%$ & 0.02 \\
\hline & Studies with intermittent Pringle maneuver & 2 & $-59.00(-87.08,-30.93)$ & $P<0.0001$ & $71 \%$ & 0.06 \\
\hline & Studies without Pringle maneuver & 1 & $-75.30(-128.95,-21.65)$ & 0.006 & - & - \\
\hline & Studies with large sample (>40) & 3 & $-72.45(-111.67,-33.23)$ & 0.0003 & $77 \%$ & 0.01 \\
\hline & Studies with small sample $(<40)$ & 2 & $-51.11(-58.05,-44.17)$ & $P<0.00001$ & 0 & 0.37 \\
\hline & Studies with dosage of $30 \mathrm{mg} / \mathrm{kg}$ & 2 & $-118.46(-223.81,-13.11)$ & 0.03 & $66 \%$ & 0.09 \\
\hline & Studies with dosage of $500 \mathrm{mg}$ & 3 & $-52.54(-62.94,-42.14)$ & $P<0.00001$ & $43 \%$ & 0.17 \\
\hline
\end{tabular}

Bold text indicates statistical significance; $R C T$, randomized controlled trial; $M D$, mean difference; OR, odds ratio; Cl, confidence interval.

graphs in original studies, because we failed to contact with corresponding author. This method may cause measurement bias.

In conclusion, preoperative administration of steroid in liver resection can promote the recovery of liver function and inhibit the inflammatory response without increasing postoperative complications. The steroid effect was associated with underlying liver disease and liver surgery itself (extent of liver resection and ischemic time), whether the steroid should be used routinely in all patients before liver resection 
remains unresolved. Further studies are required to explore this strategy.

\section{AUTHOR CONTRIBUTIONS}

WW and LY designed the study. LY and ZZ identified studies and extracted data, disagreements were resolved by discussion with WW. JK and ZZ performed the statistical analyses and prepared

\section{REFERENCES}

Aldrighetti, L., Pulitano, C., Arru, M., Finazzi, R., Catena, M., Soldini, L., et al. (2006). Impact of preoperative steroids administration on ischemia-reperfusion injury and systemic responses in liver surgery: a prospective randomized study. Liver Transpl. 12, 941-949. doi: 10.1002/lt.20745

Baigrie, R. J., Lamont, P. M., Kwiatkowski, D., Dallman, M. J., and Morris, P. J. (1992). Systemic cytokine response after major surgery. Br. J. Surg. 79, 757-760. doi: $10.1002 /$ bjs. 1800790813

Barnes, P. J. (1998). Anti-inflammatory actions of glucocorticoids: molecular mechanisms. Clin. Sci. (Lond) 94, 557-572. doi: 10.1042/cs0940557

Bartels, M., Biesalski, H. K., Engelhart, K., Sendlhofer, G., Rehak, P., and Nagel, E. (2004). Pilot study on the effect of parenteral vitamin E on ischemia and reperfusion induced liver injury: a double blind, randomized, placebocontrolled trial. Clin. Nutr. 23, 1360-1370. doi: 10.1016/j.clnu.2004.05.003

Berger, D., Bolke, E., Seidelmann, M., and Beger, H. G. (1997). Time-scale of interleukin-6, myeloid related proteins (MRP), C reactive protein (CRP), and endotoxin plasma levels during the postoperative acute phase reaction. Shock 7 , 422-426. doi: 10.1097/00024382-199706000-00006

Biffl, W. L., Moore, E. E., Moore, F. A., and Peterson, V. M. (1996). Interleukin-6 in the injured patient. Marker of injury or mediator of inflammation? Ann. Surg. 224, 647-664. doi: 10.1097/00000658-199611000-00009

Chen, L. P., Zhang, Q. H., Chen, G., Qian, Y. Y., Shi, B. Y., and Dong, J. H. (2010). Rapamycin inhibits cholangiocyte regeneration by blocking interleukin-6induced activation of signal transducer and activator of transcription 3 after liver transplantation. Liver Transpl. 16, 204-214. doi: 10.1002/lt.21985

Donadon, M., Molinari, A. F., Corazzi, F., Rocchi, L., Zito, P., Cimino, M., et al. (2016). Pharmacological modulation of ischemic-reperfusion injury during pringle maneuver in hepatic surgery. a prospective randomized pilot study. World J. Surg. 40, 2202-2212. doi: 10.1007/s00268-016-3506-1

Faist, E., Schinkel, C., and Zimmer, S. (1996). Update on the mechanisms of immune suppression of injury and immune modulation. World J. Surg. 20, 454-459. doi: $10.1007 / \mathrm{s} 002689900071$

Figueras, J., Llado, L., Ruiz, D., Ramos, E., Busquets, J., Rafecas, A., et al. (2005). Complete versus selective portal triad clamping for minor liver resections: a prospective randomized trial. Ann. Surg. 241, 582-590. doi: 10.1097/01. sla.0000157168.26021.b8

Hayashi, Y., Takayama, T., Yamazaki, S., Moriguchi, M., Ohkubo, T., Nakayama, H., et al. (2011). Validation of perioperative steroids administration in liver resection: a randomized controlled trial. Ann. Surg. 253, 50-55. doi: 10.1097/ SLA.0b013e318204b6bb

Higgins, J. P., and Thompson, S. G. (2002). Quantifying heterogeneity in a metaanalysis. Stat. Med. 21, 1539-1558. doi: 10.1002/sim.1186

Higgins, J. P., Altman, D. G., Gotzsche, P. C., Juni, P., Moher, D., Oxman, A. D., et al. (2011). The Cochrane Collaboration's tool for assessing risk of bias in randomised trials. BMJ 343, d5928. doi: 10.1136/bmj.d5928

Holte, K., and Kehlet, H. (2002). Perioperative single-dose glucocorticoid administration: pathophysiologic effects and clinical implications. J. Am. Coll. Surg. 195, 694-712. doi: 10.1016/s1072-7515(02)01491-6

Hozo, S. P., Djulbegovic, B., and Hozo, I. (2005). Estimating the mean and variance from the median, range, and the size of a sample. BMC Med. Res. Methodol. 5, 13. doi: $10.1186 / 1471-2288-5-13$

Ishikawa, Y., Yoshida, H., Mamada, Y., Taniai, N., Matsumoto, S., Bando, K., et al. (2010). Prospective randomized controlled study of short-term perioperative the relevant tables and graphs, LY drafted the manuscript and WW revised it. All authors read and approved the final version of the manuscript

\section{FUNDING}

This study was funded by the National Natural Science Foundation of China (No. 81770566). oral nutrition with branched chain amino acids in patients undergoing liver surgery. Hepatogastroenterology 57, 583-590.

Jerin, A., Pozar-Lukanovic, N., Sojar, V., Stanisavljevic, D., Paver-Erzen, V., and Osredkar, J. (2003). Balance of pro- and anti-inflammatory cytokines in liver surgery. Clin. Chem. Lab. Med. 41, 899-903. doi: 10.1515/CCLM.2003.136

Kato, M., Sawada, T., Kita, J., Shimoda, M., and Kubota, K. (2010). Erythropoietin ameliorates early ischemia-reperfusion injury following the Pringle maneuver. World J. Gastroenterol. 16, 4838-4845. doi: 10.3748/wjg.v16.i38.4838

Kawano, T., Hosokawa, N., Maruta, T., Maruta, N., and Takasaki, M. (2005). [Reevaluation of protective effects of alprostadil on hepatic function in patients undergoing hepatectomy]. Masui 54, 982-991.

Kim, Y. I., Fujita, S., Hwang, Y. J., Chun, J. M., Song, K. E., and Chun, B. Y. (2007). Successful intermittent application of the Pringle maneuver for 30 minutes during human hepatectomy: a clinical randomized study with use of a protease inhibitor. Hepatogastroenterology 54, 2055-2060.

Kimura, F., Shimizu, H., Yoshidome, H., Ohtsuka, M., Kato, A., Yoshitomi, H., et al. (2006). Circulating cytokines, chemokines, and stress hormones are increased in patients with organ dysfunction following liver resection. J. Surg. Res. 133, 102-112. doi: 10.1016/j.jss.2005.10.025

Kohl, B. A., and Deutschman, C. S. (2006). The inflammatory response to surgery and trauma. Curr. Opin. Crit. Care 12, 325-332. doi: 10.1097/01. ccx.0000235210.85073.fc

Li, H., Wei, Y., and Li, B. (2013). Preoperative steroid administration in liver resection: a systematic review and meta-analysis. Hepatogastroenterology 60, 160-169. doi: 10.5754/hge12498

Liberati, A., Altman, D. G., Tetzlaff, J., Mulrow, C., Gotzsche, P. C., Ioannidis, J. P., et al. (2009). The PRISMA statement for reporting systematic reviews and meta-analyses of studies that evaluate health care interventions: explanation and elaboration. Ann. Intern. Med. 151, W65-W94. doi: 10.7326/0003-4819-151-4-200908180-00136

Menger, M. D., and Vollmar, B. (2004). Surgical trauma: hyperinflammation versus immunosuppression? Langenbecks Arch. Surg. 389, 475-484. doi: 10.1007/ s00423-004-0472-0

Muratore, A., Ribero, D., Ferrero, A., Bergero, R., and Capussotti, L. (2003). Prospective randomized study of steroids in the prevention of ischaemic injury during hepatic resection with pedicle clamping. Br. J. Surg. 90, 17-22. doi: 10.1002/bjs.4055

Ogasawara, S., Chiba, T., Ooka, Y., Kanogawa, N., Motoyama, T., Suzuki, E., et al. (2017). A randomized placebo-controlled trial of prophylactic dexamethasone for transcatheter arterial chemoembolization. Hepatology. 67, 575-585. doi: 10.1002/hep. 29403

Polderman, J., Farhang-Razi, V., van Dieren, S., Kranke, P., DeVries, J. H., Hollmann, M. W., et al. (2019). Adverse side-effects of dexamethasone in surgical patients-an abridged Cochrane systematic review. Anaesthesia. 74, 929-939. doi: 10.1111/anae.14610

Pulitano, C., Aldrighetti, L., Arru, M., Finazzi, R., Catena, M., Guzzetti, E., et al. (2007a). Preoperative methylprednisolone administration maintains coagulation homeostasis in patients undergoing liver resection: importance of inflammatory cytokine modulation. Shock 28, 401-405. doi: 10.1097/ shk.0b013e318063ed11

Pulitano, C., Aldrighetti, L., Arru, M., Finazzi, R., Soldini, L., Catena, M., et al. (2007b). Prospective randomized study of the benefits of preoperative corticosteroid administration on hepatic ischemia-reperfusion injury and cytokine response in patients undergoing hepatic resection. HPB (Oxford) 9, 183-189. doi: 10.1080/13651820701216984 
Richardson, A. J., Laurence, J. M., and Lam, V. W. (2014). Use of pre-operative steroids in liver resection: a systematic review and meta-analysis. HPB (Oxford) 16, 12-19. doi: 10.1111/hpb.12066

Saidi, R. F., Chang, J., Verb, S., Brooks, S., Nalbantoglu, I., Adsay, V., et al. (2007). The effect of methylprednisolone on warm ischemia-reperfusion injury in the liver. Am. J. Surg. 193, 345-347; discussion 347-8. doi: 10.1016/j. amjsurg.2006.09.017

Sapolsky, R. M., Romero, L. M., and Munck, A. U. (2000). How do glucocorticoids influence stress responses? Integrating permissive, suppressive, stimulatory, and preparative actions. Endocr. Rev. 21, 55-89. doi: 10.1210/edrv.21.1.0389

Schmidt, S. C., Hamann, S., Langrehr, J. M., Hoflich, C., Mittler, J., Jacob, D., et al. (2007). Preoperative high-dose steroid administration attenuates the surgical stress response following liver resection: results of a prospective randomized study. J. Hepatobiliary Pancreat. Surg. 14, 484-492. doi: 10.1007/ s00534-006-1200-7

Shimada, H., Ochiai, T., Okazumi, S., Matsubara, H., Nabeya, Y., Miyazawa, Y., et al. (2000). Clinical benefits of steroid therapy on surgical stress in patients with esophageal cancer. Surgery 128, 791-798. doi: 10.1067/msy.2000.108614

Takeda, K., Togo, S., Kunihiro, O., Fujii, Y., Kurosawa, H., Tanaka, K., et al. (2002). Clinicohistological features of liver failure after excessive hepatectomy. Hepatogastroenterology 49, 354-358.
Teoh, N. C., and Farrell, G. C. (2003). Hepatic ischemia reperfusion injury: pathogenic mechanisms and basis for hepatoprotection. J. Gastroenterol. Hepatol. 18, 891-902. doi: 10.1046/j.1440-1746.2003.03056.x

Wustefeld, T., Rakemann, T., Kubicka, S., Manns, M. P., and Trautwein, C. (2000). Hyperstimulation with interleukin 6 inhibits cell cycle progression after hepatectomy in mice. Hepatology 32, 514-522. doi: 10.1053/jhep.2000.16604

Yamashita, Y., Shimada, M., Hamatsu, T., Rikimaru, T., Tanaka, S., Shirabe, K., et al. (2001). Effects of preoperative steroid administration on surgical stress in hepatic resection: prospective randomized trial. Arch. Surg. 136, 328-333. doi: 10.1001/archsurg.136.3.328

Conflict of Interest: The authors declare that the research was conducted in the absence of any commercial or financial relationships that could be construed as a potential conflict of interest.

Copyright (c) 2019 Yang, Zhang, Kong and Wang. This is an open-access article distributed under the terms of the Creative Commons Attribution License (CC $B Y)$. The use, distribution or reproduction in other forums is permitted, provided the original author(s) and the copyright owner(s) are credited and that the original publication in this journal is cited, in accordance with accepted academic practice. No use, distribution or reproduction is permitted which does not comply with these terms. 